OPEN ACCESS

Edited by:

Patrick C. Hanington,

University of Alberta, Canada

Reviewed by:

Han-Ching Wang,

National Cheng Kung University,

Taiwan

Chris Hauton,

University of Southampton,

United Kingdom

${ }^{*}$ Correspondence:

Jude Juventus Aweya

jjaweya@stu.edu.cn

Yueling Zhang

zhangyl@stu.edu.cn

${ }^{t}$ These authors have contributed equally to this work

Specialty section:

This article was submitted to Comparative Immunology,

a section of the journal

Frontiers in Immunology

Received: 21 June 2020 Accepted: 08 October 2020 Published: 05 November 2020

Citation:

Huang Z, Aweya JJ, Zhu C, Tran NT, Hong Y, Li S, Yao D and Zhang Y (2020) Modulation of Crustacean Innate Immune Response by Amino Acids and Their Metabolites: Inferences From Other Species.

Front. Immunol. 11:574721. doi: 10.3389/fimmu.2020.574721

\section{Modulation of Crustacean Innate Immune Response by Amino Acids and Their Metabolites: Inferences From Other Species}

\author{
Zishu Huang ${ }^{1,2 \dagger}$, Jude Juventus Aweya ${ }^{1,2^{\star t}}$, Chunhua Zhu ${ }^{3}$, Ngoc Tuan Tran ${ }^{1,2}$, \\ Yujian Hong ${ }^{4}$, Shengkang $\mathrm{Li}^{1,2}$, Defu Yao ${ }^{1,2}$ and Yueling Zhang ${ }^{1,2 *}$ \\ 1 Institute of Marine Sciences and Guangdong Provincial Key Laboratory of Marine Biotechnology, Shantou University, \\ Shantou, China, ${ }^{2}$ Shantou University-Universiti Malaysia Terengganu (STU-UMT) Joint Shellfish Research Laboratory, \\ Shantou University, Shantou, China, ${ }^{3}$ College of Fisheries, Guangdong Ocean University, Zhanjiang, China, ${ }^{4}$ Guangdong \\ Yuequn Marine Biological Research and Development Co., Ltd., Jieyang, China
}

Aquaculture production of crustaceans (mainly shrimp and crabs) has expanded globally, but disease outbreaks and pathogenic infections have hampered production in the last two decades. As invertebrates, crustaceans lack an adaptive immune system and mainly defend and protect themselves using their innate immune system. The immune system derives energy and metabolites from nutrients, with amino acids constituting one such source. A growing number of studies have shown that amino acids and their metabolites are involved in the activation, synthesis, proliferation, and differentiation of immune cells, as well as in the activation of immune related signaling pathways, reduction of inflammatory response and regulation of oxidative stress. Key enzymes in amino acid metabolism have also been implicated in the regulation of the immune system. Here, we reviewed the role played by amino acids and their metabolites in immune-modulation in crustaceans. Information is inferred from mammals and fish where none exists for crustaceans. Research themes are identified and the relevant research gaps highlighted for further studies.

Keywords: crustaceans, amino acids, metabolism, immune-modulation, innate immunity

\section{INTRODUCTION}

Crustaceans constitute an important part of the marine ecosystem, with shrimp and crabs forming a large proportion of aquatic food destined for human consumption. Over the past decade, shrimp and crab farming have expanded rapidly bringing with huge economic benefits (1). As invertebrates, crustaceans depend solely on innate immune response for defense and protection against pathogens $(2,3)$. The innate immune system is constituted by cellular and humoral immune responses (4). The cellular immune response mostly takes place in hemocytes where a variety of pattern recognition receptors (PRR) on cell membranes detect and eliminate pathogens via phagocytosis, apoptosis, nodule formation and encapsulation (5). On the other hand, the humoral immune response mainly 
depends on immune factors such as prophenoloxidase (proPO), lectins, antimicrobial peptides (AMP), etc., found in the hemolymph (6-8).

When the immune system is activated its demand for energy and metabolic substrates increases substantially. The immune system derives these metabolic substrates mainly from nutrients to provide energy as well as serve as precursors for the synthesis of new cells, effectors (e.g., antibodies, cytokines, and acute phase proteins) and protective molecules (e.g., glutathione) (9). There is therefore a close link between the immune and metabolic systems. Among all metabolic substrates required by the immune system, amino acids and their metabolites have attracted much interest $(10,11)$, probably due to their diverse functions and effect on several physiological and pathophysiological processes. For instance, arginine (Arg) can be converted to citrulline and nitric oxide (NO) under the action of nitric oxide synthase (NOS), with NO functioning as an effector molecule of tumor and microbial immunity, as well as a regulator of many immune cells (12). Arg is also catabolized to polyamines under the action of arginase and ornithine decarboxylase (ODC). In mammals, inhibition of ODC has been used in what is termed polyamineblocking therapy (PBT), a strategy that combines the inhibition of polyamine biosynthesis with the simultaneous blockade of polyamine transport to enhance anti-tumor immune response (13).

In crustaceans, amino acids and their metabolites play important roles in several physiological and pathophysiological processes including innate immune response. For instance, supplemented dietary Arg has been shown to improve the body weight and growth rate of juvenile kuruma shrimp (Penaeus japonicus) (14), while tryptophan (Trp) is capable of reducing the aggressive behavior of juvenile mud crab (Scylla serrata) as well as enhances their anti-stress ability (15). Although amino acids and their products are reported to affect the growth and immune indices of crustaceans (16-19), very few studies have explored their involvement in immune response and the molecular mechanisms involved. In any case, amino acids and/or their metabolites seem to play pivotal immune-metabolic regulatory roles in crustaceans. This review therefore brings together important findings on the effects of amino acids and their metabolites on the immune system of crustaceans, in most cases drawing inferences from other species where such information does not exist for crustaceans. Research areas are also identified with the hope that when these are further explored, it could lead to a better understanding of the role played by amino acids and their metabolites in immunemetabolic regulation in crustaceans.

\section{AMINO ACID METABOLISM AND CRUSTACEAN IMMUNITY}

As the main building blocks of proteins, amino acids are important in the growth and development of animals. Recent studies have also shown that amino acids and their metabolites play an important role in the immune system. For instance, in mammals, Arg is involved in the regulation of immune cells proliferation, by modulating the levels of NO, which consequently affect the immune system (20). Although few studies have explored the role of amino acids metabolism (metabolites) in crustacean immunity, an increasing number of studies have reported that the metabolism and/or metabolites of Arg, Trp, lysine (Lys), methionine and cysteine play key important roles in immune response in crustaceans, as in other marine species (Table 1).

\section{Arginine}

Arg is one of the most versatile amino acids that can be converted into other amino acids (proline, glutamic acid, and glutamine) or metabolized to urea via the urea cycle, as well as to polyamines, NO, creatine, and other essential non-protein substances (12). Arg is therefore an important precursor that generate metabolites and intermediates vital for the immune system. In the metabolism of Arg, arginase and NOS are two key enzymes. Arginase catalyzes the catabolism of Arg into urea and ornithine, which then generate polyamines by the action of ODC (74). Polyamines are important Arg metabolites that have antitumor effect in mammals $(75,76)$ and are also involved in the synthesis of T-cells (77). Similarly, NO, which is generated from Arg metabolism by the action of NOS, is an effective antibacterial agent against intracellular and extracellular pathogens $(24,78)$. While NO has antimicrobial effects and also modulates immune response in host cells, excess NO levels could promote peroxynitrite synthesis to generate hydroxyl radicals that cause cell damage and/or cell death $(20,79)$.

Optimum proportions and levels of amino acids are required by crustaceans for proper growth and physiological/metabolic functions, although differences exist among different species. The Pacific White shrimp Penaeus vannamei requires 4.77\% optimum level of dietary Arg (21), while 5.47\% is required by Penaeus monodon (80). Supplemented dietary Arg is reported to affect the metabolic activity of crustaceans by regulating the activity of some enzymes. For instance, aspartate aminotransferase (AST) and alanine aminotransferase (ALT), which are key enzymes in amino acids metabolism, are important indicators of hepatopancreas function in shrimp $(81,82)$. The serum levels of AST and ALT increased significantly when juvenile swimming crab (Portunus trituberculatus) were fed on low Arg diets (82). Arg supplementation also increases the activities of antioxidant enzymes and immune-related enzymes, thereby improving the antioxidant capacity, immunity, and disease resistance of juvenile P. vannamei and E. sinensis $(21,22)$.

Some Arg metabolic pathway enzymes in crustaceans are reported to modulate antimicrobial immune response. When the Caribbean spiny lobster (Panulirus argus) and red swamp crayfish (Procambarus clarkii) were challenged with Escherichia coli or lipopolysaccharide (LPS), NO levels and the activity of NOS both increased, as part of the immune response $(25,83)$. It has also been observed that when an NOS inhibitor or $P$. argus generated anti-NOS serum is administered to $P$. vannamei, it reduces bacterial clearance, further illustrating the importance of NOS in the immune defense of crustaceans $(24,83)$. 
TABLE 1 | Role of amino acids and their metabolism in the immune response of crustaceans and other marine species.

\begin{tabular}{|c|c|c|c|}
\hline Amino acid & Species & Factor/immune response & Reference \\
\hline \multirow[t]{6}{*}{ Arginine } & $\begin{array}{l}\text { Penaeus vannamei; Eriocheir } \\
\text { sinensis }\end{array}$ & Dietary Arg improves antioxidant enzyme activity and immune response & $(21,22)$ \\
\hline & P. vannamei & Increased NO and NOS mRNA levels to improve antibacterial immune response & (23) \\
\hline & P. vannamei; Panulirus argus & Increased NO levels and NOS activity to improve antibacterial immune response & $(24,25)$ \\
\hline & Penaeus japonicus & Decreased arginine kinase activity attenuates WSSV replication & (26) \\
\hline & Paphia malabarica & Increased iNOS activity as an antibacterial immune response & (27) \\
\hline & Megalobrama amblycephala & Dietary Arg improves antioxidant capacity and immune response & (28) \\
\hline \multirow[t]{6}{*}{ Tryptophan } & E. sinensis & $\begin{array}{l}\text { Dietary Trp increases dominant intestinal bacteria abundance, serum CAT and AKP activity, and } \\
\text { improves immune response }\end{array}$ & (29) \\
\hline & E. sinensis & Dietary Trp increases THC, hemocyanin, ACP and ALP activity, and hemocyte phagocytic activity & (30) \\
\hline & E. sinensis & Melatonin (injected) increases THC, hemocyanin, and activity of ACP and GSH-Px & (31) \\
\hline & E. sinensis & $\begin{array}{l}\text { Melatonin restores oxidative damage, stabilizes } \mathrm{ACP}, \mathrm{AKP} \text {, and } \mathrm{Na}^{+}-\mathrm{K}^{+} \text {-ATPase activity, increase Cyt-C } \\
\text { content, restores apoptotic rate and phagocytic activity of hemocytes }\end{array}$ & (32) \\
\hline & E. sinensis & Melatonin (injected) increases SOD activity and decrease MDA content to enhance antioxidant capacity & (33) \\
\hline & Dicentrarchus labrax & Increase Trp levels decrease inflammatory response via immunosuppression & (34) \\
\hline \multirow[t]{5}{*}{ Lysine } & $\begin{array}{l}\text { Astacus leptodactylus } \\
\text { leptodactylus }\end{array}$ & L -carnitine improves antioxidant defense by increasing activities of PO, SOD, GSH and GPX & (35) \\
\hline & Apostichopus japonicus & Increased Lys enhances CAT and AKP activity to improve antioxidant and immune response & (36) \\
\hline & Ctenopharyngodon idella & Dietary Lys increases SOD, GPX and Nrf2 levels to improve lipid and protein oxidation & (37) \\
\hline & Acanthopagrus schlegelii & Dietary carnitine increases LZM and CAT activity, but inhibits expression of pro-inflammatory factors & (38) \\
\hline & Rhynchocypris lagowski & Carnitine reduces inflammatory response by Nrf2/Keap1 activation to inhibit NF- $\kappa B$ signaling pathway & (39) \\
\hline \multirow[t]{7}{*}{$\begin{array}{l}\text { Methionine and } \\
\text { cysteine }\end{array}$} & $\begin{array}{l}\text { Oreochromis niloticus; } D \text {. } \\
\text { labrax }\end{array}$ & $\begin{array}{l}\text { Dietary Met increases C3 and C4 levels, CAT, GPX, and LZM activity to enhance immune response and } \\
\text { antioxidant capacity }\end{array}$ & $(40,41)$ \\
\hline & Dicentrarchus labrax & Met promotes immune cells proliferation by regulating polyamines synthesis & (42) \\
\hline & D. labrax & Met enhances leukocytes proliferation and reduces expression of pro-inflammatory genes & (43) \\
\hline & E. sinensis & GSH supplementation promotes expression of immune genes (alf1 alf2 alf3, crus1, and crus2),, & (44) \\
\hline & E. sinensis & $\begin{array}{l}\text { Dietary GSH increases SOD, GPX and GST activity to resist oxidative stress. Also reduces apoptosis by } \\
\text { inhibiting expression of caspase- } 3 \text {, caspase- } 8 \text {, and caspase- } 9\end{array}$ & $(45)$ \\
\hline & P. vannamei & Dietary GSH increases ACP, AKP and SOD activity, and sensitivity to $V$. alginolyticus infection & $(46)$ \\
\hline & E. sinensis & Taurine supplementation increases expression of immune genes and AMPs & $(47)$ \\
\hline \multirow{5}{*}{$\begin{array}{l}\text { Branched chain } \\
\text { amino acid }\end{array}$} & M. amblycephala & Leu increases antioxidant enzyme activity and the levels of C3 and IgM & (48) \\
\hline & Labeo rohita & $\begin{array}{l}\text { Leu increases expression of LZM, C3, } \beta \text {-microglobulin, IgM, SOD, GPx, Nrf2, NKF- } \beta \text {, and TLR22, and } \\
\text { decreases TNF- } \beta \text {, Keap1, and IL-1B }\end{array}$ & (49) \\
\hline & Paralichthys olivaceus & lle enhance respiratory burst and total lg content & $(50)$ \\
\hline & Trachinotus ovatus & Val increases LZM activity and levels of C3, C4, and IgM & $(51)$ \\
\hline & Portunus trituberculatus & Dietary Leu improves antioxidant capacity by increasing PO and SOD activity & (52) \\
\hline \multirow{4}{*}{$\begin{array}{l}\text { Glutamate and } \\
\text { glutamine }\end{array}$} & Cyprinus carpio var. Jian & Glu supplementation induces Nrf2 to enhance antioxidant enzymes activity & (53) \\
\hline & Oreochromis niloticus & $\begin{array}{l}\text { Gln supplementation improves macrophages phagocytosis and bactericidal ability. Promote lymphocyte } \\
\text { proliferation }\end{array}$ & (54) \\
\hline & Oncorhynchus mykiss & Gln increases number of B-lymphocytes and secretion of Igs through NODs signaling pathway & $(55)$ \\
\hline & P. vannamei & Glu-driven anaplerosis provides ATP and lipids for WSSV replication & $(56,57)$ \\
\hline \multirow[t]{3}{*}{ Phenylalanine } & Danio rerio & Phe helps clear drug-resistant bacteria (e.g. Vibrio alginoyticus), through an unknown pathway & (58) \\
\hline & $\begin{array}{l}\text { Oreochromis niloticus } \times \\
\text { Oreochromis aureus }\end{array}$ & Dietary Phe increases LZM and CAT activity & (59) \\
\hline & C. idella & Phe supplementation increases expression of intestinal IL-10, TGF- $\beta 1$, TOR, IкB $\alpha$, and Nrf2 & (60) \\
\hline \multirow[t]{4}{*}{ Tyrosine } & P. vannamei & $\begin{array}{l}\text { Tyrosine hydroxylase knockdown enhances immune response and delays the decreased immune } \\
\text { response under low temperature stress }\end{array}$ & $(61,62)$ \\
\hline & Macrobrachium rosenbergii & $\begin{array}{l}\text { DA (injected) suppresses immune response and increases susceptibility to Lactococcus garvieae } \\
\text { infection }\end{array}$ & (63) \\
\hline & Penaeus monodon & $\begin{array}{l}\text { DA (injected) suppresses immune response and increases susceptibility to Photobacterium damsela } \\
\text { infection }\end{array}$ & $(64)$ \\
\hline & P. vannamei & $\begin{array}{l}\text { DA receptor coupling with G protein activates the CAMP- PKA, DAG-PKC, or CAM pathway to regulate } \\
\text { immune response }\end{array}$ & $(65)$ \\
\hline Proline & P. vannamei & Pro supplementation improves antioxidant and immune capacity & (66) \\
\hline \multirow[t]{3}{*}{ Histidine } & M. amblycephala & Dietary His inhibits nuclear import of Nrf2 and decreases expression of antioxidant enzymes & $(67)$ \\
\hline & C. idella & $\begin{array}{l}\text { His deficiency/excess cause oxidative damage, increases pro-inflammatory factors and decreases anti- } \\
\text { inflammatory factors expression }\end{array}$ & (68) \\
\hline & E. sinensis & Histamine increases PO and SOD activity but decreases levels of THC, ACP, and AKP & (69) \\
\hline
\end{tabular}


TABLE 1 | Continued

\begin{tabular}{|c|c|c|c|}
\hline Amino acid & Species & Factor/immune response & Reference \\
\hline \multirow[t]{3}{*}{ Threonine } & C. idella & $\begin{array}{l}\text { Thr deficiency decreases LZM and ACP activity, and levels of C3, C4, and IgM. Decreases expression of } \\
\text { AMPs }\end{array}$ & (70) \\
\hline & M. amblycephala & Thr supplementation increases levels of C3, C4 and IgM, and activity of SOD, CAT, and GPX & $(71)$ \\
\hline & M. amblycephala & Excess or deficient Thr causes damage to antioxidant and immune systems & (72) \\
\hline Glycine & C. idella & Gly and N-acetyl cysteine (NAC) supplementation improves antioxidant capacity & (73) \\
\hline \multicolumn{4}{|c|}{ 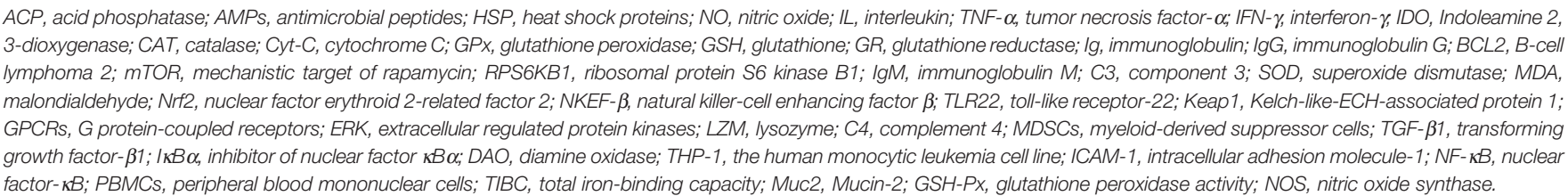 } \\
\hline
\end{tabular}

Arg kinase is one of the most important enzymes that regulates energy metabolism in invertebrates (84). Invertebrates mainly store their energy in the form of Arg phosphate, which is converted to ATP and Arg by the action of Arg kinase during energy (ATP) demand, while under ATP saturation, Arg kinase catalyzes the synthesis of Arg phosphate as energy store (85). This could be one of the reasons why in crustacean Arg kinase levels change in response to immune stimulation and virus infection $(84,86,87)$. In P. japonicus, the Arg kinase homolog MjAK is reported to promote WSSV replication while the Cdc42 homolog MjCdc42, inhibits WSSV replication by interacting with the active site of MjAK to inhibit its enzyme activity (26). Levels of Arg and Arg metabolites as well as the activity of Arg kinase therefore affect energy homeostasis in crustaceans, which consequently affect the immune system (Figure 1).

\section{Tryptophan}

The aromatic amino acid, Trp, is an essential amino acid in most animals (including crustaceans) that must be obtained from diets, as it cannot be de novo synthesized. In addition to its role as a protein building block, Trp is metabolized into other active substances via two main pathways, i.e., (i) conversion to 5hydroxytryptophan under the action of Trp hydroxylase, which is decarboxylated to serotonin (5-HT), and then finally to melatonin (MT) by N-acetyltransferase, (ii) Trp is also metabolized to kynurenine, catalyzed by $\operatorname{Trp} 2$, 3-dioxygenase (TDO), and indoleamine 2, 3-dioxygenase (IDO), and then to acetyl-CoA and nicotinamide adenine dinucleotide (NAD+) (88, 89). Thus, Trp and its metabolites play important roles in many metabolic, physiological, and pathophysiological functions including immunity (90-93).

Most core metabolic reactions are conserved across many organisms, highlighting the fundamental role of metabolism [reviewed by (94)]. Thus, due to the paucity of information on the role of metabolic pathway components in some species, comparative studies or inferences are drawn from other organisms. For Trp metabolism, numerous mammalian studies have shown its involvement in diverse immune-related functions. For instance, Trp affects the gut immunity of piglets and mice by decreasing the expression of cytokines (e.g., TNF- $\alpha$, IL-6, IL-1 $\beta$, IL-17, etc.) and inducing the expression of proapoptotic caspase- 8 and Bax (95). Trp also activates the aryl hydrocarbon receptor (AhR) transcription factor (96), a key regulator of immunity and inflammation in mammals (97), therefore essential for maintaining intestinal immunity and barrier function $(98,99)$. Despite these beneficial effects of Trp, high levels of dietary Trp could adversely affect the morphology of intestinal epithelium and tight junction proteins (100). Key enzymes in the Trp metabolic pathway have also been implicated in immune regulation. It has been reported that IDO and AhR work together to link microbial Trp catabolism and host Trp metabolites to regulate T-cells function in intestine, especially in T-cells immunity that depends on AhR [see recent review by (101)]. During infection of humans by the parasite Toxoplasma gondii, host cells synthesize Interferon- $\gamma($ IFN- $\gamma$ ) to activate IDO, so as to degrade Trp, and therefore prevent $T$. gondii replication $(102,103)$. The Trp metabolite serotonin $(5-\mathrm{HT})$ has also been implicated in immune response in mammals, as intestinal microbiota are able to modulate host immune response by altering levels of 5-HT in models of mucosal infections (104, $105)$, thereby attenuating the ability to mount immune response to disease pathogens (106-108).

There is no comprehensive information on Trp metabolism in marine species as compared to terrestrial mammals, especially the role Trp plays in immune-related functions. Nonetheless, Trp and its metabolites are reported to play several physiological and immune-related functions in marine animals. In crustaceans, dietary Trp supplementation improves the growth index and survival rate $(29,109)$. It has also been shown that $\operatorname{Trp}$ (metabolites) decreases the aggressive behavior (fights/attacks) of juvenile $S$. serrata $(15,110)$, improves reproduction in $P$. monodon (111) and freshwater crab (Barytelphusa guerini) (109), as well as embryonic development of the giant freshwater prawn Macrobrachium rosenbergii (112). In terms of immunity, Trp supplementation increases intestinal microbiota of E. sinensis, resulting in higher survival rates upon bacterial challenge (29). While loss of limbs in crabs decreases their immunity and survival rate $(113,114)$, dietary $\operatorname{Trp}$ supplementation improves their immune indices [e.g., the total hemocyte count (THC), phagocytosis rate, acid phosphatase (ACP), and alkaline phosphatase (ALP) activity, etc.] as well as antioxidant capacity (30). The Trp metabolite melatonin, affects the immune system and antioxidant defense system (ADS) of crustaceans $(33,115)$. When eyestalk-ablated $E$. sinensis were injected with melatonin, both their immune and antioxidant capacity were enhanced in terms of increased THC and hemocyanin levels, coupled with an elevation 


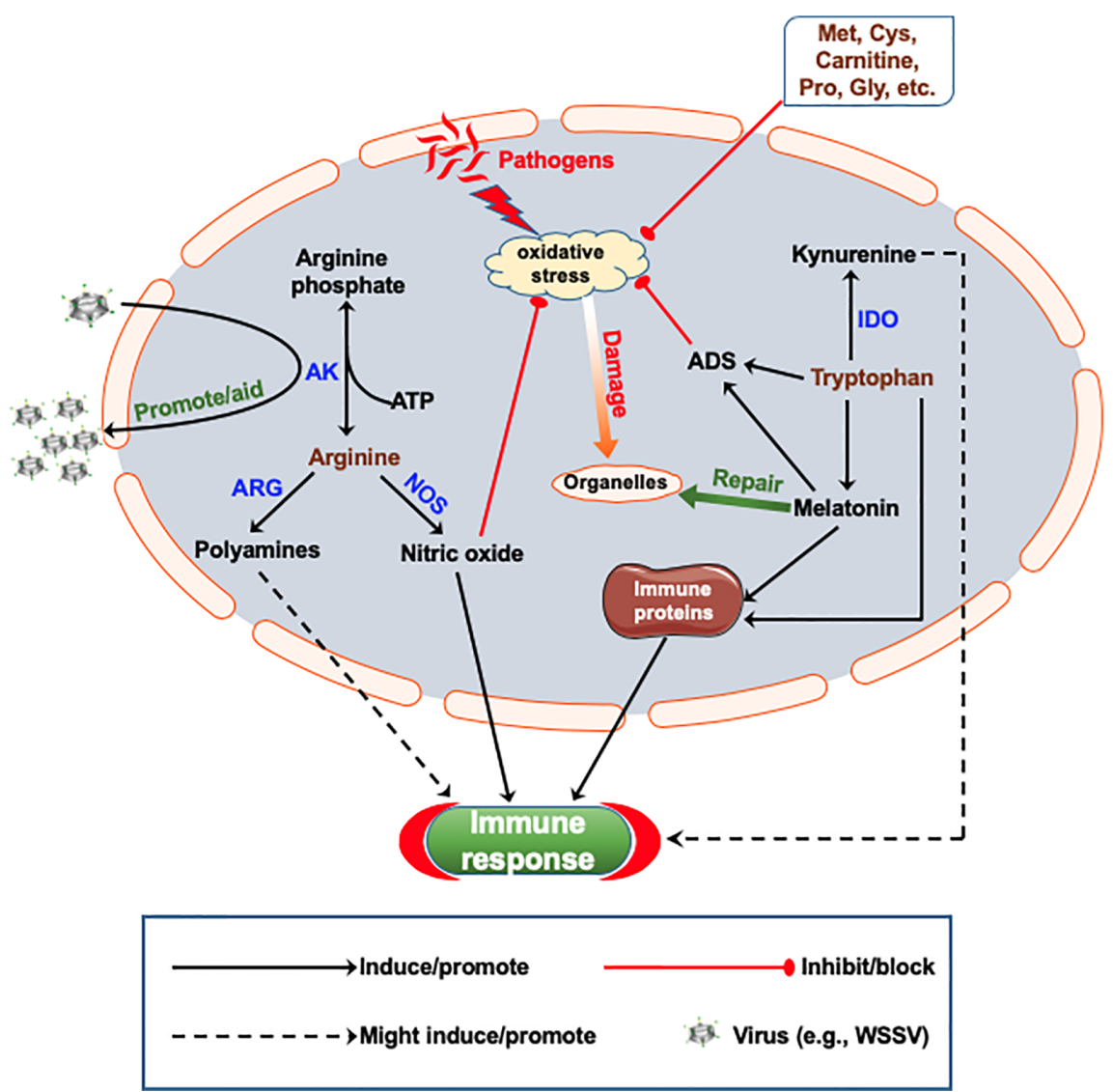

FIGURE 1 | Proposed schematic representation of how amino acids metabolism and immune-modulation occur in crustaceans. Nitric oxide (NO) is generated from arginine (Arg) by the action of nitric oxide synthase (NOS), which counteracts pathogen-induced oxidative stress and promote immune response. Polyamines, as downstream products of Arg metabolism, promote immune response, while arginine kinase (AK) can catalyze the conversion of Arg to arginine phosphate, which can be coopted to promote replication of white spot syndrome virus (WSSV). Tryptophan (Trp) and its metabolite melatonin can activate the antioxidant system (ADS) and promote the expression of immune proteins as well as counteract oxidative stress. Melatonin also promotes the repair of oxidative stress induced organelle damage. Trp could also suppress inflammatory response through the kynurenine pathway. Some amino acids such as Met, Cys, Pro, Gly, etc., have direct antioxidant activity due to their chemical properties. IDO, Indoleamine-2,3-dioxygenase; ARG, Arginase; Met, methionine; Cys, cysteine; Pro, proline; Gly, glycine.

in the activities of ALP, ACP, superoxide dismutase (SOD), glutathione peroxidase (GSH-Px), and other antioxidant enzymes (31). Melatonin injection also enhances response to oxidative damage and elimination of damaged mitochondria and hemocytes due to external stress in E. sinensis (32). There are however differences in the effect of melatonin in various tissues, as it does not exert direct effect on the ADS of gills in the estuarine crab (Neohelice granulata) but enhances that of muscle by increasing glutathione (GSH) content and glutamate cysteine ligase ( $\gamma$ - GCL) activity $(116,117)$. Although increased Trp levels tend to decrease the inflammatory response in fish (Dicentrarchus labrax) due to immunosuppression by Trp metabolism (34), there is dearth of information as to whether elevated levels of Trp and/or its metabolism have similar immunosuppressive effect in crustaceans. In any case, enough evidence points to the fact that Trp and its metabolites are involved in different aspects of immune regulation in crustaceans (Figure 1), although details of the immune-metabolic mechanisms remain unknown. More studies are needed to further explore the molecular mechanisms of immunomodulation by Trp and its metabolites in crustaceans.

\section{Lysine}

Most animals must obtain Lys from their diets as it is an essential amino acid, which cannot be synthesized by the body. In mammals, L-lysine can be irreversibly converted into glutamate and $\alpha$-aminoadipic acid through glycolysis, before being further deaminated and oxidized (118). In addition to protein synthesis, Lys can combine with methionine to form carnitine (38), which is involved in the transfer of long-chain fatty acid acyl groups to mitochondria for $\beta$-oxidation (119). The optimal dietary intake of Lys differs in different marine species and also exerts different effects on physiological and biochemical indices $(36,120-124)$. For example, in fish, the daily optimal Lys requirement for juvenile dusky kob or Giant kob (Argyrosomus 
japonicus) is $7.35 \%$ of the diet (125), while that of juvenile silver perch (Bidyanus bidyanus) is 5.96\% (126). It has been observed that within a certain range, increasing Lys intake increases body weight and specific growth rate (SGR) of Totoaba macdonaldi (123), while excessive Lys intake affects growth and feed utilization in large yellow croaker (Pseudosciaena crocea; Richardson, 1846) (127). On the other hand, lack of Lys in B. bidyanus reduces the crude protein content of whole body, muscle and liver, but increases fat content (126).

Varying optimal dietary amounts of Lys have also been reported in different crustaceans. In juvenile Atlantic ditch shrimp (Palaemonetes varians), optimal Lys levels of $2.42 \%-$ $2.63 \%$ have been reported (128), with $1.64 \%$ reported for P. vannamei (18), while $2.17 \%$ has been reported for juvenile $P$. trituberculatus (16). In $M$. rosenbergii, increased levels of Lys affect Arg retention, which suggests some antagonism between Arg and Lys levels (129), probably because they are both absorbed via the same brush border membrane carrier (130). Dietary Lys supplementation affect various physiological and biochemical indices in crustaceans including SGR, weight gain (WG), feed efficiency, protein efficiency ratio, protein deposition ratio, as well as AST and ALT activities (127). The activities of pepsin, trypsin and other digestive enzymes are also reported to increase upon adding the appropriate levels of Arg and Lys to diets of $M$. rosenbergii (129), while dietary Lys affects intestinal protease levels and activity of ALP in juvenile sea cucumber (Apostichopus japonicus) (36).

There is no direct evidence of the involvement of Lys in immune regulation in crustaceans. However, in many species, some amino acids, their metabolites as well as enzymes involved in their metabolic pathways have been directly or indirectly implicated in immune regulation [see review by (131) (Wu and Meininger, 2002)]. For instance, dietary carnitine (Lys metabolite) has been shown to increase the activity of lysozyme (LZM) and catalase (CAT) in serum and liver of juvenile black seabream (Acanthopagrus schlegelii) as well as increase the antioxidant capacity, but reduces inflammatory response $(38,39,132)$. In crustacean, dietary supplementation of carnitine improves growth, increase feed utilization and the antioxidant system in juvenile narrow clawed crayfish (Astacus leptodactylus leptodactylus; Eschscholtz, 1823) (35). Most of the research on the involvement of carnitine in immune regulation in marine animals has mainly been in fish (133-135), with none on crustaceans. It is believed that carnitine regulates nutrition metabolism to enhance anti-stress response, as dietary carnitine increases lipids utilization rate to produce more energy and reduce amino acids catabolism, thereby reducing lipids peroxidation and promoting protein synthesis (136). Although few studies have explored the molecular mechanisms involved in Lys metabolism in crustacean, given that most core metabolic reactions are conserved across many organisms (94), coupled with the importance of Lys in immuno-regulation and its antagonism with Arg, the role of Lys in crustacean immunity could be inferred from other species. In any case, specific studies in crustacean are needed to explore the immune-metabolic functions of Lys, especially the involvement of Lys in the Arg-NO pathway or other immune-related pathways.

\section{Methionine and Cysteine}

Methionine (Met) and cysteine (Cys) are two sulfur-containing amino acids that are involved in various metabolic pathways and affect several biological functions. There are three main pathways through which Met is metabolized including (i) protein synthesis; (ii) conversion to S-adenosylmethionine (SAM), an important methyl donor in the formation of polyamines, or transmethylation of SAM to S-adenosylhomocysteine (SAH), which is further hydrolyzed to homocysteine (Hcy). Hcy can be remethylated to Met by Betaine-homocysteine methyltransferase (BHMT) and Methyltetrahydrofolate-homocysteine methyltransferase (MS); (iii) irreversible conversion of Hcy to cystathionine through the transsulfhydryl reaction, and then further to cysteine $(137,138)$. Met and its metabolites possess antioxidant capacity, as Met residues are very sensitive to oxidation and can inactivate reactive oxygen species (ROS) $(139,140)$. Thus, Met acts as an antioxidant to protect proteins and other macromolecules from oxidative damage $(141,142)$.

The involvement of Met metabolism in immune-related functions have been extensively studied in mammals, which means that inferences could be drawn from such studies to explain similar phenomenon in crustacean, given that core metabolic pathways are conserved across species. In mammals, high dietary Met content improves IgG levels and percentage of lymphocytes, as well as pathological changes due to infectious bursal disease (143). As an important immune organ in birds, bursa plays a pivotal role in immunity, hence, lack of Met inhibits the development of the bursa of Fabricius, which affects the humoral immunity of chicken (144). Dietary Met supplementation also affects the expression of inflammation-related genes $(145,146)$, and impact positively on gut immunity in mammals (147-149). Similarly, the addition of Met dipeptides to feed reduces the harmful effects of Eimeria spp. on the gut of broilers (150), while lack of Met in feed could attenuate WG, intestinal development and intestinal mucosal immunity in broilers and pigs $(151,152)$, or reduce resistance to parasites in rats (153).

A growing number of studies have explored the effects of dietary Met supplementation on immune-metabolic modulation in marine animals including crustaceans. Most of these studies have, however, been focused on fish. For instance, dietary Met supplements have been shown to improve growth performance in different fish species $(144,154-158)$. Specifically, lack of Met in feed could affect protein synthesis and reduce feed utilization in flatfish (Solea senegalensis) and white bass (Morone chrysops) $(159,160)$, as well as induce general mitochondrial dysfunction in liver of rainbow trout (Oncorhynchus mykiss) (161). On the contrary, excess dietary Met does not result in a corresponding improvement in growth rate in O. mykiss or orange-spotted grouper (Epinephelus coioides) $(156,162)$, and could even decrease growth rate in $P$. crocea (157). In the European sea bass D. labrax, dietary Met increases the number of immune cells upon immune stimulation (34), as Met is used as a precursor for the synthesis of polyamines, which is required for the regulation 
of immune cells proliferation (42). Dietary Met also improves immunity, by increasing leukocyte proliferation but decreases the pro-inflammatory index in D. labrax (43), juvenile yellow catfish (Pelteobagrus fulvidraco) (163) and juvenile Nile tilapia (Oreochromis niloticus) (40). Similarly, Met levels can potentiate the activity of SOD in juvenile O. niloticus (40), and increase the activities of CAT and GSH-Px in juvenile D. labrax (41). Despite the very few number of studies that have reported on the involvement of Met in crustacean immunity, dietary Met supplementation has been shown to improve growth performance in shrimp ( $P$. vannamei and P. monodon) (164, 165). The question then is, does Met and its metabolites also improve the immune response and antioxidant ability in crustaceans, as observed in fish and other species? This remains an open question.

Cysteine possess special chemical properties that makes it easily oxidized like Met $(166,167)$, for which reason it is often used as an indicator of oxidative damage (168). The detailed metabolic pathway and functions of Cys and/or its metabolites in immune-metabolic modulation in crustaceans have not been well elucidated as in mammals, although they could be similar due to conserved core metabolic pathways across species. For instance, in mammals such as piglets, Cys is reported to improve the intestinal inflammatory response induced by dextran sodium sulfate (DSS) (169), due to the ability of Cys to decrease intestinal oxidative stress (147). Dietary Cys is reported to increase the expression of proliferating cell nuclear antigen, occludin and claudin-1 after LPS stimulation in weaned piglets, because Cys is able to protect intestinal integrity (170). While Cys is required for T-cells activation in mammals (88), T-cells are unable to convert Met into Cys, and do not have the cystine transporter to transfer cystine, which means that Cys must be provided to Tcells by antigen-presenting cells (APC) (171). Thus, in the absence of Cys, T-cells activation is attenuated and the synthesis of glutathione and DNA in cells is blocked, which eventually result in functional damage and apoptosis (172-174). During Cys metabolism, it can also combine with glutamate and glycine to form the tripeptide glutathione (GSH) in a two-step reaction catalyzed by $\gamma$-l-glutamyl-1-cysteine:glycine ligase and glutathione synthetase (175). As an important antioxidant that scavenge free radicals and ROS (176) to prevent oxidative stress, GSH has been implicated in many cellular reactions including immune regulation. In mammals, GSH is required for lymphocyte proliferation, T-cells activation and cytokine production (177-179). In addition, GSH inhibits inflammatory response (180), as well as enhance innate and adaptive immunity in humans by providing protection against microbial infection (181). Mammals also metabolize Cys to taurine or ethanesulfonic acid, one of the most abundant amino acids in cells (172) (Grimble, 2006), which plays a key role in immunomodulation (182, 183).

Limited number of studies have explored the role of Cys and its metabolites in immune-metabolic modulation in crustaceans. Nonetheless, it has been shown that dietary Cys and Met supplementation improves survival rate, feed intake, and food conversion rate in P. vannamei (154). In the kuruma shrimp
P. japonicus, Cys and GSH have been shown to improve growth, inhibit phenoloxidase (PO) activity, and reduce browning due to o-quinones (184). Similarly, dietary GSH supplementation in Chinese mitten crab (E. sinensis), increased the levels of total protein, albumin (alB) and globulin (glB) in hemolymph, upregulated the expression of immune-related genes (44), and reduced LPS-induced pathological damage to the hepatopancreas, as well as decreased ROS levels and apoptosis (45). Dietary GSH supplementation in P. vannamei has also been shown to increase the activity of ACP, AKP, and SOD, while decreasing shrimp susceptible to $V$. alginolyticus infection (46). In crustaceans, taurine has been shown to improve growth and immunity by increasing body weight, SGR, expression of intestinal immune genes and antimicrobial peptides in E. sinensis (47), and improve the growth performance of P. vannamei (185). In spite of the fact that no specific studies have so far explored the role of Cys and Met or their metabolites in crustacean immunity, there are enough evidence to suggest that these amino acids play key roles in crustacean immunity. Further research should therefore explore how Cys and Met or their metabolites modulate crustacean immune response and the molecular mechanisms involved.

\section{Other Amino Acids}

The branched chain amino acids (BCAA) leucine, isoleucine and valine, which are essential amino acids in animals (186), are important for growth, development and immunity $(187,188)$. Leucine (Leu) acts as a nutrient signal that regulates T-cells by activating mTORC1 (189). The mTOR signaling pathway is important for immune response, cell metabolism and other biochemical reactions (190), as it receives and organizes signals from the surrounding environment to direct T-cells differentiation and function in mammals (191). Isoleucine (Ile) is associated with intestinal immunity and can activate G-protein coupled receptors (GPCR) and extra-cellular signal-regulated kinase (ERK) signaling pathways, thereby increasing the expression of human $\beta$-defensin-2 (HBD2) (192), an important antimicrobial peptide involved in gut innate immunity (193). In fish, such as grass carp (Ctenopharyngodon idella), increase dietary Leu content within a certain range results in an increase in the mRNA level of Nrf2 [nuclear factor erythroid 2 -related factor $2(\mathrm{Nrf} 2)$ ] in muscle that also shows a positive correlation with the expression of antioxidant enzymes, indicating that Leu enhances antioxidant capacity by increasing the activity of antioxidant enzymes (194). Increasing levels of Leu supplements also improves the immune capacity of juvenile blunt snout bream (Megalobrama amblycephala) by elevating the levels of complement component 3 (C3) and IgM (48). The effects of BCAAs on immune function has also been shown in juvenile golden pompano (Trachinotus ovatus) (51), juvenile olive flounder (Paralichthys olivaceus) (50), and Labeo rohita fingerlings (49). For crustaceans, dietary Leu intake has been reported to improve growth performance (195), and antioxidant capacity by increasing the activity of PO and SOD in juvenile $P$. trituberculatus (52). While the effects of Leu on the antioxidant system and the molecular mechanism involved have not been 
reported in crustaceans, it could be similar to that of fish or other marine species due to synonymous metabolic pathways found in different species. Further studies could explore this aspect of Leu's role in crustacean immune response.

Glutamine (Gln) is the most abundant free amino acid in mammals (196), and plays a key role in immune response by supporting T-cells proliferation (197), macrophage development (198) and intestinal immunity (199). In marine animals, Gln supplementation can improve the antioxidant capacity of juvenile gilthead sea bream (Sparus aurata) (200) and enhance macrophages phagocytosis and bactericidal ability in O. niloticus (54). Similarly, in O. mykiss, Gln is reported to inhibit LPSinduced inflammatory response through the NOD signaling pathway (55). Very few studies have so far explored Gln metabolism and its metabolites on crustacean immunity. In a recent study, it has been revealed that a different type of anaplerosis exist in P. vannamei, where WSSV-infected cells were more likely to ingest glutamate than glutamine, as the virus activates mTORC2, glutamate dehydrogenase (GDH) and aspartate aminotransferase (ASAT) to catabolize excess glutamate in the hemolymph into $\alpha-K G$, so as to maintain the TCA cycle and to support viral replication (56). In addition, $\alpha$ KG can also be converted into isocitrate, and then used for the synthesis of lipids required by WSSV (57).

For the aromatic amino acids phenylalanine (Phe) and tyrosine (Tyr), Phe has been implicated in mammalian immune response (88), as it regulates T-cells proliferation and activation (201). Among aquatic animals, most of the studies involving the aromatic amino acids, especially Phe, has been in fish. For instance, Phe is reported to promote lysozyme expression in Danio rerio, acting as an essential amino acid for the elimination of resistant Vibrio alginolyticus (58), while in juvenile hybrid tilapia (Oreochromis niloticus $\times$ Oreochromis aureus), Phe levels affect immune performance (59). There are relatively few studies on Phe in crustaceans, which have mainly focused on the dietary requirements of Phe for optimal growth (202). Tyrosine hydroxylase, a key enzyme in Tyr metabolism, catalyzes the conversion of Tyr to L-DOPA, which then forms the catecholamines (dopamine, norepinephrine, and epinephrine) (203). Silencing of tyrosine hydroxylase has been shown to enhance the immunity of $P$. vannamei, even under low temperature stress $(61,62)$. Similarly, the catecholamine dopamine (DA) is reported to affect the immunity of crustaceans, as it suppresses the immune response of shrimp ( $P$. monodon and $M$. rosenbergii) as well as increase their susceptibility to bacteria (Lactococcus garvieae and Photobacterium damsela) infection. DA receptors also couple with $G$ protein to activate the cyclic adenylate (cAMP)-PKA, DAG-PKC or CaM pathway to regulate the immune system, and modulate the activities of antioxidant enzymes $(63-65,204)$. Thus, the enhancement of crustacean immunity after tyrosine hydroxylase silencing is achieved due to an inhibition of DA (or other catecholamines) synthesis.

Proline (Pro) is a key amino acid involved in protein synthesis (205) and an important regulator of metabolism (206), immunity (66), and together with its metabolite, hydroxyproline, play an important role in collagen synthesis and tissue repair (207). Proline metabolism plays an essential part in innate immune response, as infection of Caenorhabditis elegans with $P$. aeruginosa, results in the catabolism of Pro into P5C by proline dehydrogenase $(\mathrm{PRODH})$, with the resultant $\mathrm{P} 5 \mathrm{C}$ regulating ROS homeostasis and $\mathrm{SKN}-1$ activation, to induce antibacterial response (208). Limited studies have explored the role of proline in crustaceans, but Pro is reported to play a role in the immune system of shrimp, where dietary Pro supplementation has been shown to improve the antioxidant and immune capacity of P. vannamei (66).

Recent studies have reported that histidine (His) plays an important role in the antioxidant capacity of fish. For instance, low His diets have been shown to inhibit the nuclear import of Nrf2 and to decrease the expression of antioxidant enzymes in juvenile M. amblycephala (67) and young C. idella (68). In crustaceans, the His metabolite, histamine, is reported to affect the immunity of E. sinensis by increasing the activities of $\mathrm{PO}$ and SOD, while decreasing the levels of THC, ACP, and AKP as well as the activities of intestinal digestive enzymes $(69,209)$.

Threonine (Thr) plays an important role in intestinal immunity (210), with high levels (3\%) of dietary Thr shown to improve the intestinal tract of broilers and increase the IgA levels of ileum to enhance immune response (211). Deficiency of Thr is reported to induce decrease in lysozyme activity, and reduce the levels of C3, C4, and IgM as well as some anti-inflammatory factors, thereby impairing the growth and development of juvenile C. idella (70). Thr levels have also been reported to affect the growth performance of crustaceans. In juvenile $P$. vannamei, the SGR and protein efficiency ratio increased with dietary Thr supplementation, coupled with increased activity of SOD and PO $(19,212)$.

Dietary glycine (Gly) supplementation has been shown to increase WG and SRG of P. vannamei (213), while Gly and Nacetyl cysteine (NAC) supplementation improves the antioxidant capacity of $C$. idella (73). Alanine (Ala) has been implicated in the regulation of T-cells activation in mice (214) with no report in marine species. For the other amino acids such as serine (Ser), aspartate (Asp), and asparagine (Asn), there are currently no published reports on their role in crustacean immune-metabolic regulation. Despite the fact that there are currently no reported studies on the involvement of these amino acids and/or their metabolites in crustacean immunity, the importance of these amino acids in most organisms coupled with the fact that core metabolic pathways are conserved across species, it is plausible to conceive that these amino acids could also play vital roles in crustacean immune modulation. Further studies are needed in order to ascertain the involvement of these amino acids in immune-modulation in crustaceans.

\section{CONCLUSION AND FUTURE PERSPECTIVES}

Amino acid metabolism is essential for maintaining normal growth and for generating metabolites important for 
physiological and pathophysiological processes in the body. The immune system, which is pivotal in protecting and defending the body from pathogens, is nourished and regulated by amino acids and their metabolites $(215,216)$. While some amino acids including cysteine, alanine, glutamine, etc., have been shown to directly affect the activation, proliferation, and differentiation of immune cells $(88,198,214)$, key enzymes involved in amino acid metabolism have also been implicated as key regulators of the immune system $(12,208)$. Most of the research findings on the role played by amino acids and their metabolites in immunomodulation has been in mammals, with very few studies on crustaceans. Nevertheless, given that the core metabolic pathways are conserved across species, and the fact that exogenous supplementation of amino acids and amino acid metabolites have been shown to drastically improve the antioxidant capacity and immune parameters in fish and crustaceans, it indicates the importance of amino acids in immune-metabolic modulation in crustaceans. For instance, details are emerging on the pathogenicity and infection mechanism of WSSV, which requires glutamic acid for replication in shrimp (56). During Arg metabolism, increased activity of NOS has been shown to enhance functions of the immune system in P. vannamei, while Arg kinase promotes WSSV replication $(24,26)$. This suggests that Arg might be the bridge between energy metabolism and immune response.

In mammalian studies, Trp metabolites have been used as ligands to activate AhR (217), so as to regulate host intestinal immunity, which in turn, affects the composition of intestinal microbiota such as Clostridium sporogenes, Ruminococcus gnavus, Lactobacillus, Clostridium, Bacteroides, etc. (101). Similarly, Trp supplementation can enhance the immunity and antioxidant capacity of crustaceans, as well as increase intestinal microbiota $(29,30)$, which suggest that intestinal microbiota regulate the immune system of crustaceans via Trp metabolites. Trp metabolism may therefore reveal the relationship between crustaceans and microorganisms. In addition, studies in fish show that amino acids and their metabolites can regulate the immune system by activating immune related signaling pathways or enhance the synthesis of immune proteins. Since amino acids undergo similar

\section{REFERENCES}

1. FAO. The State of World Fisheries and Aquaculture 2018. In: Contributing to Food Security and Nutrition for All. Rome: FAO (2018). p. 66-7.

2. Little TJ, Hultmark D, Read AF. Invertebrate immunity and the limits of mechanistic immunology. Nat Immunol (2005) 6(7):651-4. doi: 10.1038/ ni1219

3. Hanington PC, Forys MA, Dragoo JW, Zhang SM, Adema CM, Loker ES. Role for a somatically diversified lectin in resistance of an invertebrate to parasite infection. Proc Natl Acad Sci USA (2010) 107(49):21087-92. doi: 10.1073/pnas.1011242107

4. Fredrick WS, Ravichandran S. Hemolymph proteins in marine crustaceans. Asian Pac J Trop BioMed (2012) 2(6):496-502. doi: 10.1016/S2221-1691(12)60084-7

5. Lin X, Soderhall I. Crustacean hematopoiesis and the astakine cytokines. Blood (2011) 117(24):6417-24. doi: 10.1182/blood-2010-11-320614

6. Soderhall K, Cerenius L. Role of the prophenoloxidase-activating system in invertebrate immunity. Curr Opin Immunol (1998) 10(1):23-8. doi: 10.1016/s0952-7915(98)80026-5 metabolism in different species, it suggests that in crustaceans amino acids may also improve their immune response through similar mechanisms (Figure 1).

Crustacean farming has been hampered by several diseases and pathogens (218), as there is still limited understanding of their molecular immunology. Thus, to fully understand the immune response mechanisms of crustaceans, it is necessary to explore and delineate the key molecular factors such as amino acids and/or their metabolites that are involved in the modulation of these processes. Such insight would enable the institution of prudent and more effective disease control measures. Knowledge of immunomodulation by amino acids or their metabolites from similar studies in other animals such as fish could be inferred and possibly leveraged for useful application in crustacean aquaculture.

\section{AUTHOR CONTRIBUTIONS}

JA and YZ conceived the idea. ZH and JA performed the literature search, wrote, and revised the paper. YZ obtained funding and provided supervision. CZ, NT, YH, SL, and DF provided literature input and suggestions. All authors contributed to the article and approved the submitted version.

\section{FUNDING}

This work was sponsored by National Natural Science Foundation of China (No.31872596), Department of Education of Guangdong Province (No.2017KZDXM033), and Science and Technology Planning Project of Guangdong Province (2017B020245001).

\section{ACKNOWLEDGMENTS}

We thank all members of the Shrimp Disease and Immunology Laboratory for the exchange of ideas and for providing constructive critique of the manuscript.

7. Wongpanya R, Sengprasert P, Amparyup P, Tassanakajon A. A novel Ctype lectin in the black tiger shrimp Penaeus monodon functions as a pattern recognition receptor by binding and causing bacterial agglutination. Fish Shellfish Immunol (2017) 60:103-13. doi: 10.1016/j.fsi.2016.11.042

8. Wu B, Zhang C, Qin X, Shi L, Zhao M. Identification and function of penaeidin 3 and penaeidin 5 in Fenneropenaeus merguiensis. Fish Shellfish Immunol (2019) 89:623-31. doi: 10.1016/j.fsi.2019.04.032

9. Fernstrom JD. Branched-chain amino acids and brain function. J Nutr (2005) 135(6 Suppl):1539S-46S. doi: 10.1093/jn/135.6.1539S

10. Yang B, Wang X, Ren X. Amino acid metabolism related to immune tolerance by MDSCs. Int Rev Immunol (2012) 31(3):177-83. doi: 10.3109/08830185.2012.679989

11. Moura CS, Lollo PCB, Morato PN, Risso EM, Amaya-Farfan J. Modulatory effects of arginine, glutamine and branched-chain amino acids on heat shock proteins, immunity and antioxidant response in exercised rats. Food Funct (2017) 8(9):3228-38. doi: 10.1039/c7fo00465f

12. Wu G, Bazer FW, Davis TA, Kim SW, Li P, Marc Rhoads J, et al. Arginine metabolism and nutrition in growth, health and disease. Amino Acids (2009) 37(1):153-68. doi: 10.1007/s00726-008-0210-y 
13. Casero RA Jr., Murray Stewart T, Pegg AE. Polyamine metabolism and cancer: treatments, challenges and opportunities. Nat Rev Cancer (2018) 18 (11):681-95. doi: 10.1038/s41568-018-0050-3

14. Alam MS, Teshima S, Ishikawa M, Hasegawa D, Koshio S. Dietary arginine requirement of juvenile kuruma shrimp Marsupenaeus japonicus (Bate). Aquac Res (2004) 35(9):842-9. doi: 10.1111/j.1365-2109.2004.01075.x

15. Leopoldo J, Laranja Q, Quinitio ET, Catacutan MR, Coloso RM. Effects of dietary L-tryptophan on the agonistic behavior, growth and survival of juvenile mud crab Scylla serrata. Aquaculture (2010) 310(1-2):84-90. doi: 10.1016/j.aquaculture.2010.09.038

16. Jin M, Wang MQ, Huo YW, Huang WW, Mai KS, Zhou QC. Dietary lysine requirement of juvenile swimming crab, Portunus trituberculatus. Aquaculture (2015) 448:1-7. doi: 10.1016/j.aquaculture.2015.05.021

17. Sun YP, Guan LZ, Xiong JH, Xi QY, Zhang YL. Effects of L-tryptophansupplemented dietary on growth performance and 5-HT and GABA levels in juvenile Litopenaeus vannamei. Aquacult Int (2015) 23(1):235-51. doi: 10.1007/s10499-014-9811-5

18. Xie FJ, Zeng WP, Zhou QC, Wang HL, Wang T, Zheng CQ, et al. Dietary lysine requirement of juvenile Pacific white shrimp, Litopenaeus vannamei. Aquaculture (2012) 358:116-21. doi: 10.1016/j.aquaculture.2012.06.027

19. Zhou QC, Wang YL, Wang HL, Tan BP. Dietary threonine requirements of juvenile Pacific white shrimp, Litopenaeus vannamei. Aquaculture (2013) 392:142-7. doi: 10.1016/j.aquaculture.2013.01.026

20. Wu G. Arginine and immune function. In: PC Calder and P Yaqoob, editors. Diet, Immunity and Inflammation. Cambridge, UK: Woodhead Publishing (2013). doi: 10.1533/9780857095749.3.523

21. Zhou QC, Zeng WP, Wang HL, Wang T, Wang YL, Xie FJ. Dietary arginine requirement of juvenile Pacific white shrimp, Litopenaeus vannamei. Aquaculture (2012) 364(1):252-8. doi: 10.1016/j.aquaculture.2012.08.020

22. Qi C, Wang X, Han F, Jia Y, Lin Z, Wang C, et al. Arginine supplementation improves growth, antioxidant capacity, immunity and disease resistance of juvenile Chinese mitten crab, Eriocheir sinensis. Fish Shellfish Immunol (2019) 93:463-73. doi: 10.1016/j.fsi.2019.07.082

23. Chen T, Wong NK, Jiang X, Luo X, Zhang L, Yang D, et al. Nitric oxide as an antimicrobial molecule against Vibrio harveyi infection in the hepatopancreas of Pacific white shrimp, Litopenaeus vannamei. Fish Shellfish Immunol (2015) 42(1):114-20. doi: 10.1016/j.fsi.2014.10.042

24. Rodriguezramos T, Carpio Y, Bolivar J, Gomez L, Estrada MP, Pendon C. Nitric oxide synthase-dependent immune response against gram negative bacteria in a crustacean, Litopenaeus vannamei. Fish Shellfish Immunol (2016) 50:50-5. doi: 10.1016/j.fsi.2016.01.019

25. Rodriguezramos T, Carpio Y, Ramos L, Pons T, Farnos O, Iglesias C, et al. New aspects concerning to the characterization and the relationship with the immune response in vivo of the spiny lobster Panulirus argus nitric oxide synthase. Nitric Oxide (2011) 25(4):396-406. doi: 10.1016/j.niox.2011.09.002

26. Xu JD, Jiang HS, Wei TD, Zhang KY, Wang XW, Zhao XF, et al. Interaction of the Small GTPase Cdc42 with Arginine Kinase Restricts White Spot Syndrome Virus in Shrimp. J Virol (2017) 91(5):e01916-16. doi: 10.1128/ JVI.01916-16

27. Gajbhiye DS, Khandeparker L. Involvement of inducible nitric oxide synthase (iNOS) in immune-functioning of Paphia malabarica (Chemnitz, 1782). Fish Shellfish Immunol (2019) 84:384-9. doi: 10.1016/j.fsi.2018.10.025

28. Liang H, Ji K, Ge X, Ren M, Liu B, Xi B, et al. Effects of dietary arginine on antioxidant status and immunity involved in AMPK-NO signaling pathway in juvenile blunt snout bream. Fish Shellfish Immunol (2018) 78:69-78. doi: 10.1016/j.fsi.2018.04.028

29. Yang X, Xu M, Huang G, Zhang C, Pang Y, Cheng Y. Effect of dietary Ltryptophan on the survival, immune response and gut microbiota of the Chinese mitten crab, Eriocheir sinensis. Fish Shellfish Immunol (2019) 84:1007-17. doi: 10.1016/j.fsi.2018.10.076

30. Zhang C, Zhang Q, Song X, Pang Y, Song Y, Cheng Y, et al. Dietary LTryptophan Modulates the Hematological Immune and Antibacterial Ability of the Chinese Mitten Crab, Eriocheir sinensis, Under Cheliped Autotomy Stress. Front Immunol (2018) 9:2744. doi: 10.3389/ fimmu.2018.02744

31. Zhang C, Yang XZ, Xu MJ, Huang GY, Zhang Q, Cheng YX, et al. Melatonin Promotes Cheliped Regeneration, Digestive Enzyme Function, and
Immunity Following Autotomy in the Chinese Mitten Crab, Eriocheir sinensis. Front Physiol (2018) 9:269. doi: 10.3389/fphys.2018.00269

32. Zhang C, Zhang Q, Pang Y, Song X, Zhou N, Wang J, et al. The protective effects of melatonin on oxidative damage and the immune system of the Chinese mitten crab (Eriocheir sinensis) exposed to deltamethrin. Sci Total Environ (2019) 653:1426-34. doi: 10.1016/j.scitotenv.2018.11.063

33. She Q, Han Z, Liang S, Xu W, Li X, Zhao Y, et al. Impacts of circadian rhythm and melatonin on the specific activities of immune and antioxidant enzymes of the Chinese mitten crab (Eriocheir sinensis). Fish Shellfish Immunol (2019) 89:345-53. doi: 10.1016/j.fsi.2019.04.011

34. Azeredo R, Serra CR, Oliva-Teles A, Costas B. Amino acids as modulators of the European seabass, Dicentrarchus labrax, innate immune response: an in vitro approach. Sci Rep (2017) 7(1):18009. doi: 10.1038/s41598-017-18345-3

35. Safari O, Atash MMS, Paolucci M. Effects of dietary L-carnitine level on growth performance, immune responses and stress resistance of juvenile narrow clawed crayfish, Astacus leptodactylus leptodactylus Eschscholtz, 1823. Aquaculture (2015) 439:20-8. doi: 10.1016/j.aquaculture.2015.01.019

36. Liu CM, Han YZ, Ren TJ, Jiang ZQ, Wang FQ, Liao ML, et al. Effects of Dietary Lysine Levels on Growth, Intestinal Digestive Enzymes, and Coelomic Fluid Nonspecific Immune Enzymes of Sea Cucumber, Apostichopus japonicus, Juveniles. J World Aquacult Soc (2017) 48 (2):290-302. doi: 10.1111/jwas.12344

37. Li XY, Liu Y, Jiang WD, Jiang J, Wu P, Zhao J, et al. Co- and Post-Treatment with Lysine Protects Primary Fish Enterocytes against Cu-Induced Oxidative Damage. PloS One (2016) 11(1):e0147408. doi: 10.1371/journal.pone. 0147408

38. Jin M, Pan TT, Cheng X, Zhu TT, Sun P, Zhou F, et al. Effects of supplemental dietary L-carnitine and bile acids on growth performance, antioxidant and immune ability, histopathological changes and inflammatory response in juvenile black seabream (Acanthopagrus schlegelii) fed high-fat diet. Aquaculture (2019) 504:199-209. doi: 10.1016/ j.aquaculture.2019.01.063

39. Zhang DM, Guo ZX, Zhao YL, Wang QJ, Gao YS, Yu T, et al. L-carnitine regulated Nrf2/Keap1 activation in vitro and in vivo and protected oxidized fish oil-induced inflammation response by inhibiting the NF-kappaB signaling pathway in Rhynchocypris lagowski Dybowski. Fish Shellfish Immunol (2019) 93:1100-10. doi: 10.1016/j.fsi.2019.08.041

40. He JY, Long WQ, Han B, Tian LX, Yang HJ, Zeng SL, et al. Effect of dietary L-methionine concentrations on growth performance, serum immune and antioxidative responses of juvenile Nile tilapia, Oreochromis niloticus. Aquac Res (2017) 48(2):665-74. doi: 10.1111/are.12913

41. Coutinho F, Simoes R, Monge-Ortiz R, Furuya WM, Pousao-Ferreira P, Kaushik S, et al. Effects of dietary methionine and taurine supplementation to low-fish meal diets on growth performance and oxidative status of European sea bass (Dicentrarchus labrax) juveniles. Aquaculture (2017) 479:447-54. doi: 10.1016/j.aquaculture.2017.06.017

42. Azeredo R, Machado M, Afonso A, Fierro-Castro C, Reyes-Lopez FE, Tort L, et al. Neuroendocrine and Immune Responses Undertake Different Fates following Tryptophan or Methionine Dietary Treatment: Tales from a Teleost Model. Front Immunol (2017) 8:1226. doi: 10.3389/fimmu. 2017.01226

43. Machado M, Azeredo R, Fontinha F, Fernandez-Boo S, Conceicao LEC, Dias J, et al. Dietary Methionine Improves the European Seabass (Dicentrarchus labrax) Immune Status, Inflammatory Response, and Disease Resistance. Front Immunol (2018) 9:2672. doi: 10.3389/fimmu.2018.02672

44. Liu JD, Chi C, Zheng XC, Xu CY, Zhang CY, Ye MW, et al. Effect of dietary glutathione supplementation on the immune responses and the fatty acid and amino acid composition in Chinese mitten crab, Eriocheir sinensis. Aquacult Rep (2019) 15:100217. doi: 10.1016/j.aqrep.2019.100217

45. Liu J, Liu W, Zhang C, Xu C, Zheng X, Zhang D, et al. Dietary glutathione supplementation enhances antioxidant activity and protects against lipopolysaccharide-induced acute hepatopancreatic injury and cell apoptosis in Chinese mitten crab, Eriocheir sinensis. Fish Shellfish Immunol (2020) 97:440-54. doi: 10.1016/j.fsi.2019.12.049

46. Xia Z, Wu S. Effects of glutathione on the survival, growth performance and non-specific immunity of white shrimps (Litopenaeus vannamei). Fish Shellfish Immunol (2018) 73:141-4. doi: 10.1016/j.fsi.2017.12.015 
47. Dong J, Cheng R, Yang Y, Zhao Y, Wu G, Zhang R, et al. Effects of dietary taurine on growth, non-specific immunity, anti-oxidative properties and gut immunity in the Chinese mitten crab Eriocheir sinensis. Fish Shellfish Immunol (2018) 82:212-9. doi: 10.1016/j.fsi.2018.08.029

48. Liang H, Mokrani A, Ji K, Ge X, Ren M, Xie J, et al. Dietary leucine modulates growth performance, Nrf2 antioxidant signaling pathway and immune response of juvenile blunt snout bream (Megalobrama amblycephala). Fish Shellfish Immunol (2018) 73:57-65. doi: 10.1016/ j.fsi.2017.11.048

49. Giri SS, Sen SS, Chi C, Kim HJ, Yun S, Park SC, et al. Effect of dietary leucine on the growth parameters and expression of antioxidant, immune, and inflammatory genes in the head kidney of Labeo rohita fingerlings. Vet Immunol Immunopathol (2015) 167(1-2):36-43. doi: 10.1016/ j.vetimm.2015.07.004

50. Rahimnejad A, Lee KJ. Dietary Isoleucine Influences Non-Specific Immune Response in Juvenile Olive Flounder (Paralichthys olivaceus). Turkish J Fish Aquat Sci (2014) 14(4):853-62. doi: 10.4194/1303-2712-v14_4_02

51. Huang Z, Tan XH, Zhou CP, Yang YK, Qi CL, Zhao SY, et al. Effect of dietary valine levels on the growth performance, feed utilization and immune function of juvenile golden pompano, Trachinotus ovatus. Aquac Nutr (2018) 24(1):74-82. doi: 10.1111/anu.12535

52. Huo YW, Jin M, Sun P, Hou YM, Li Y, Qiu H, et al. Effect of dietary leucine on growth performance, hemolymph and hepatopancreas enzyme activities of swimming crab, Portunus trituberculatus. Aquac Nutr (2017) 23(6):134150. doi: 10.1111/anu.12509

53. Zhao Y, Li JY, Yin L, Feng L, Liu Y, Jiang WD, et al. Effects of dietary glutamate supplementation on flesh quality, antioxidant defense and gene expression related to lipid metabolism and myogenic regulation in Jian carp (Cyprinus carpio var. Jian). Aquaculture (2019) 502:212-22. doi: 10.1016/ j.aquaculture.2018.12.050

54. Carvalho P, Yamamoto FY, Barros MM, Gatlin Iii DM. l-glutamine in vitro supplementation enhances Nile tilapia Oreochromis niloticus (Linnaeus, 1758) leukocyte function. Fish Shellfish Immunol (2018) 80:592-9. doi: 10.1016/j.fsi.2018.06.043

55. Li S, Guo Q, Li S, Zheng H, Chi S, Xu Z, et al. Glutamine protects against LPS-induced inflammation via adjusted NODs signaling and enhanced immunoglobulins secretion in rainbow trout leukocytes. Dev Comp Immunol (2019) 98:148-56. doi: 10.1016/j.dci.2019.05.006

56. Li CY, Wang YJ, Huang SW, Cheng CS, Wang HC. Replication of the Shrimp Virus WSSV Depends on Glutamate-Driven Anaplerosis. PloS One (2016) 11(1):e0146902. doi: 10.1371/journal.pone.0146902

57. He ST, Lee DY, Tung CY, Li CY, Wang HC. Glutamine Metabolism in Both the Oxidative and Reductive Directions Is Triggered in Shrimp Immune Cells (Hemocytes) at the WSSV Genome Replication Stage to Benefit Virus Replication. Front Immunol (2019) 10:2102. doi: 10.3389/fimmu. 2019.02102

58. Jiang M, Gong QY, Lai SS, Cheng ZX, Chen ZG, Zheng J, et al. Phenylalanine enhances innate immune response to clear ceftazidime-resistant Vibrio alginolyticus in Danio rerio. Fish Shellfish Immunol (2019) 84:912-9. doi: 10.1016/j.fsi.2018.10.071

59. Xiao W, Zou ZY, Li DY, Zhu JL, Yue YR, Yang H. Effect of dietary phenylalanine level on growth performance, body composition, and biochemical parameters in plasma of juvenile hybrid tilapia, Oreochromis niloticus x Oreochromis aureus. J World Aquacult Soc (2020) 51(2):437-51. doi: 10.1111/jwas.12641

60. Lin F, Wen L, Yang L, Wei-Dan J, Sheng-Yao K, Jun J, et al. Dietary phenylalanine-improved intestinal barrier health in young grass carp (Ctenopharyngodon idella) is associated with increased immune status and regulated gene expression of cytokines, tight junction proteins, antioxidant enzymes and related signallin. Fish Shellfish Immunol (2015) 45(2):495-509. doi: 10.1016/j.fsi.2015.05.001

61. Mapanao R, Chang CC, Cheng W. The upregulation of immune responses in tyrosine hydroxylase (TH) silenced Litopenaeus vannamei. Dev Comp Immunol (2017) 67:30-42. doi: 10.1016/j.dci.2016.11.002

62. Mapanao R, Chang CC, Cheng W, Liu KF. Silencing tyrosine hydroxylase retards depression of immunocompetence of Litopenaeus vannamei under hypothermal stress. Fish Shellfish Immunol (2018) 72:519-27. doi: 10.1016/ j.fsi.2017.11.035
63. Li JT, Lee PP, Chen OC, Cheng W, Kuo CM. Dopamine depresses the immune ability and increases susceptibility to Lactococcus garvieae in the freshwater giant prawn, Macrobrachium rosenbergii. Fish Shellfish Immunol (2005) 19(3):269-80. doi: 10.1016/j.fsi.2005.01.003

64. Chang CC, Wu ZR, Kuo CM, Cheng W. Dopamine depresses immunity in the tiger shrimp Penaeus monodon. Fish Shellfish Immunol (2007) 23(1):2433. doi: 10.1016/j.fsi.2006.09.001

65. Tong R, Wei C, Pan L, Zhang X. Effects of dopamine on immune signaling pathway factors, phagocytosis and exocytosis in hemocytes of Litopenaeus vannamei. Dev Comp Immunol (2020) 102:103473. doi: 10.1016/ j.dci.2019.103473

66. Xie SW, Tian LX, Li YM, Zhou WW, Zeng SL, Yang HJ, et al. Effect of proline supplementation on anti-oxidative capacity, immune response and stress tolerance of juvenile Pacific white shrimp, Litopenaeus vannamei. Aquaculture (2015) 448:105-11. doi: 10.1016/j.aquaculture.2015.05.040

67. Yang Q, Liang HL, Mokrani A, Ji K, Yu H, Ge XP, et al. Dietary histidine affects intestinal antioxidant enzyme activities, antioxidant gene expressions and inflammatory factors in juvenile blunt snout bream (Megalobrama amblycephala). Aquac Nutr (2019) 25(1):249-59. doi: 10.1111/anu.12847

68. Jiang WD, Feng L, Qu B, Wu P, Kuang SY, Jiang J, et al. Changes in integrity of the gill during histidine deficiency or excess due to depression of cellular anti-oxidative ability, induction of apoptosis, inflammation and impair of cell-cell tight junctions related to Nrf2, TOR and NF-kappaB signaling in fish. Fish Shellfish Immunol (2016) 56:111-22. doi: 10.1016/ j.fsi.2016.07.002

69. Zhao LL, Yang XZ, Cheng YX, Liang P, Zhang JB, Hong YH, et al. Effects of Histamine on Survival and Immune Parameters of the Chinese Mitten Crab, Eriocheir Sinensis. J Shellfish Res (2012) 31(3):827-34. doi: 10.2983/ 035.031.0329

70. Dong YW, Jiang WD, Liu Y, Wu P, Jiang J, Kuang SY, et al. Threonine deficiency decreased intestinal immunity and aggravated inflammation associated with NF-kappaB and target of rapamycin signalling pathways in juvenile grass carp (Ctenopharyngodon idella) after infection with Aeromonas hydrophila. Br J Nutr (2017) 118(2):92-108. doi: 10.1017/ S0007114517001830

71. Habtetsion H, Ren M, Liu B, Ge X, Xie J, Chen R. Threonine modulates immune response, antioxidant status and gene expressions of antioxidant enzymes and antioxidant-immune-cytokine-related signaling molecules in juvenile blunt snout bream (Megalobrama amblycephala). Fish Shellfish Immunol (2016) 51:189-99. doi: 10.1016/j.fsi.2015.11.033

72. Habtetsion H, Ge X, Liu B, Xie J, Ren M, Zhou Q, et al. A deficiency or an excess of dietary threonine level affects weight gain, enzyme activity, immune response and immune-related gene expression in juvenile blunt snout bream (Megalobrama amblycephala). Fish Shellfish Immunol (2015) 42(2):439-46. doi: 10.1016/j.fsi.2014.11.021

73. Xie S, Tian L, Niu J, Liang G, Liu Y. Effect of N-acetyl cysteine and glycine supplementation on growth performance, glutathione synthesis, and antioxidative ability of grass carp, Ctenopharyngodon idella. Fish Physiol Biochem (2017) 43(4):1011-20. doi: 10.1007/s10695-017-0348-1

74. Morris SMJr. Arginine Metabolism Revisited. J Nutr (2016) 146(12):2579S86S. doi: 10.3945/jn.115.226621

75. Ye C, Geng Z, Dominguez D, Chen S, Fan J, Qin L, et al. Targeting Ornithine Decarboxylase by alpha-Difluoromethylornithine Inhibits Tumor Growth by Impairing Myeloid-Derived Suppressor Cells. J Immunol (2016) 196 (2):915-23. doi: 10.4049/jimmunol.1500729

76. Hayes CS, Burns MR, Gilmour SK. Polyamine blockade promotes antitumor immunity. Oncoimmunology (2014) 3(1):e27360. doi: 10.4161/onci.27360

77. Hesterberg RS, Cleveland JL, Epling-Burnette PK. Role of Polyamines in Immune Cell Functions. Med Sci (Basel) (2018) 6(1):22. doi: 10.3390/ medsci6010022

78. Bogdan C. Nitric oxide synthase in innate and adaptive immunity: an update. Trends Immunol (2015) 36(3):161-78. doi: 10.1016/j.it.2015.01.003

79. Garciaortiz A, Serrador JM. Nitric Oxide Signaling in T Cell-Mediated Immunity. Trends Mol Med (2018) 24(4):412-27. doi: 10.1016/ j.molmed.2018.02.002

80. Chen H, Leu YT, Roelants I. Quantification of arginine requirements of juvenile marine shrimp, Penaeus monodon, using microencapsulated arginine. Mar Biol (1992) 114(2):229-33. doi: 10.1007/BF00349523 
81. Yan Q, Xie S, Zhu X, Lei W, Yang Y. Dietary methionine requirement for juvenile rockfish, Sebastes schlegeli. Aquac Nutr (2007) 13(3):163-9. doi: 10.1111/j.1365-2095.2007.00461.x

82. Jin M, Zhou QC, Wang MQ, Huo YW, Huang WW, Mai KS. Dietary arginine requirement of juvenile swimming crab, Portunus trituberculatus. Aquac Nutr (2016) 22(6):1174-84. doi: 10.1111/anu.12350

83. Yeh FC, Wu SH, Lai CY, Lee CY. Demonstration of nitric oxide synthase activity in crustacean hemocytes and anti-microbial activity of hemocytederived nitric oxide. Comp Biochem Physiol B Biochem Mol Biol (2006) 144 (1):11-7. doi: 10.1016/j.cbpb.2006.01.007

84. Yao CL, Wu CG, Xiang JH, Dong B. Molecular cloning and response to laminarin stimulation of arginine kinase in haemolymph in Chinese shrimp, Fenneropenaeus chinensis. Fish Shellfish Immunol (2005) 19(4):317-29. doi: 10.1016/j.fsi.2005.01.006

85. Morris S, van Aardt WJ, Ahern MD. The effect of lead on the metabolic and energetic status of the Yabby, Cherax destructor, during environmental hypoxia. Aquat Toxicol (2005) 75(1):16-31. doi: 10.1016/j.aquatox.2005. 07.001

86. Astrofsky KM, Roux MM, Klimpel KR, Fox JG, Dhar AK. Isolation of differentially expressed genes from white spot virus (WSV) infected Pacific blue shrimp (Penaeus stylirostris). Arch Virol (2002) 147(9):1799-812. doi: 10.1007/s00705-002-0845-Z

87. Wang B, Li F, Dong B, Zhang X, Zhang C, Xiang J. Discovery of the genes in response to white spot syndrome virus (WSSV) infection in Fenneropenaeus chinensis through cDNA microarray. Mar Biotechnol (NY) (2006) 8(5):491500. doi: 10.1007/s10126-005-6136-4

88. Grohmann U, Bronte V. Control of immune response by amino acid metabolism. Immunol Rev (2010) 236(1):243-64. doi: 10.1111/j.1600065X.2010.00915.X

89. Yao K, Fang J, Yin YL, Feng ZM, Tang ZR, Wu G. Tryptophan metabolism in animals: important roles in nutrition and health. Front Biosci (Schol Ed) (2011) 3(1):286-97. doi: 10.2741/s152

90. Hoseini SM, Perez-Jimenez A, Costas B, Azeredo R, Gesto M. Physiological roles of tryptophan in teleosts: current knowledge and perspectives for future studies. Rev Aquacult (2019) 11(1):3-24. doi: 10.1111/raq.12223

91. McGaha TL, Huang L, Lemos H, Metz R, Mautino M, Prendergast GC, et al. Amino acid catabolism: a pivotal regulator of innate and adaptive immunity. Immunol Rev (2012) 249(1):135-57. doi: 10.1111/j.1600-065X.2012.01149.x

92. Nowak EC, de Vries VC, Wasiuk A, Ahonen C, Bennett KA, Le Mercier I, et al. Tryptophan hydroxylase-1 regulates immune tolerance and inflammation. J Exp Med (2012) 209(11):2127-35. doi: 10.1084/ jem.20120408

93. Zhang E, Dong S, Wang F, Tian X, Gao Q. Effects of l-tryptophan on the growth, intestinal enzyme activities and non-specific immune response of sea cucumber (Apostichopus japonicus Selenka) exposed to crowding stress. Fish Shellfish Immunol (2018) 75:158-63. doi: 10.1016/ j.fsi.2018.01.009

94. Peregrin-Alvarez JM, Sanford C, Parkinson J. The conservation and evolutionary modularity of metabolism. Genome Biol (2009) 10(6):R63. doi: 10.1186/gb-2009-10-6-r63

95. Kim CJ, Kovacs-Nolan JA, Yang C, Archbold T, Fan MZ, Mine Y. 1Tryptophan exhibits therapeutic function in a porcine model of dextran sodium sulfate (DSS)-induced colitis. J Nutr Biochem (2010) 21(6):468-75. doi: 10.1016/j.jnutbio.2009.01.019

96. Islam J, Sato S, Watanabe K, Watanabe T, Ardiansyah, Hirahara K, et al. Dietary tryptophan alleviates dextran sodium sulfate-induced colitis through aryl hydrocarbon receptor in mice. J Nutr Biochem (2017) 42:43-50. doi: 10.1016/j.jnutbio.2016.12.019

97. Korecka A, Dona A, Lahiri S, Tett AJ, Al-Asmakh M, Braniste V, et al. Bidirectional communication between the Aryl hydrocarbon Receptor (AhR) and the microbiome tunes host metabolism. NPJ Biofilms Microbiomes (2016) 2:16014. doi: 10.1038/npjbiofilms.2016.14

98. Sutter CH, Bodreddigari S, Campion C, Wible RS, Sutter TR. 2,3,7,8Tetrachlorodibenzo-p-dioxin increases the expression of genes in the human epidermal differentiation complex and accelerates epidermal barrier formation. Toxicol Sci (2011) 124(1):128-37. doi: 10.1093/toxsci/ kfr205
99. Qiu J, Heller JJ, Guo X, Chen ZM, Fish K, Fu YX, et al. The aryl hydrocarbon receptor regulates gut immunity through modulation of innate lymphoid cells. Immunity (2012) 36(1):92-104. doi: 10.1016/j.immuni.2011.11.011

100. Tossou MC, Liu H, Bai M, Chen S, Cai Y, Duraipandiyan V, et al. Effect of High Dietary Tryptophan on Intestinal Morphology and Tight Junction Protein of Weaned Pig. BioMed Res Int (2016) 2016:2912418. doi: 10.1155/ 2016/2912418

101. Gao J, Xu K, Liu H, Liu G, Bai M, Peng C, et al. Impact of the Gut Microbiota on Intestinal Immunity Mediated by Tryptophan Metabolism. Front Cell Infect Microbiol (2018) 8:13. doi: 10.3389/fcimb.2018.00013

102. Dai W, Pan H, Kwok O, Dubey JP. Human indoleamine 2,3-dioxygenase inhibits Toxoplasma gondii growth in fibroblast cells. J Interferon Res (1994) 14(6):313-7. doi: 10.1089/jir.1994.14.313

103. Hucke C, MacKenzie CR, Adjogble KD, Takikawa O, Daubener W. Nitric oxide-mediated regulation of gamma interferon-induced bacteriostasis: inhibition and degradation of human indoleamine 2,3-dioxygenase. Infect Immun (2004) 72(5):2723-30. doi: 10.1128/iai.72.5.2723-2730.2004

104. Margolis KG, Stevanovic K, Li Z, Yang QM, Oravecz T, Zambrowicz B, et al. Pharmacological reduction of mucosal but not neuronal serotonin opposes inflammation in mouse intestine. Gut (2014) 63(6):928-37. doi: 10.1136/ gutjnl-2013-304901

105. De Vadder F, Grasset E, Manneras Holm L, Karsenty G, Macpherson AJ, Olofsson LE, et al. Gut microbiota regulates maturation of the adult enteric nervous system via enteric serotonin networks. Proc Natl Acad Sci USA (2018) 115(25):6458-63. doi: 10.1073/pnas.1720017115

106. Stoll ML, Kumar R, Lefkowitz EJ, Cron RQ, Morrow CD, Barnes S. Fecal metabolomics in pediatric spondyloarthritis implicate decreased metabolic diversity and altered tryptophan metabolism as pathogenic factors. Genes Immun (2016) 17(7):400-5. doi: 10.1038/gene.2016.38

107. Reigstad CS, Salmonson CE, Rainey JF, Szurszewski JH, Linden DR, Sonnenburg JL, et al. Gut microbes promote colonic serotonin production through an effect of short-chain fatty acids on enterochromaffin cells. FASEB $J$ (2015) 29(4):1395-403. doi: 10.1096/fj.14-259598

108. Levin AD, van den Brink GR. Selective inhibition of mucosal serotonin as treatment for IBD? Gut (2014) 63(6):866-7. doi: 10.1136/gutjnl-2013-305283

109. Prasad GL, Naik BR, Ko JE, Nagaraju GP. Effects of naloxone, serotonin, and dopamine on reproduction of the freshwater crab Barytelphusa guerini. J Exp Zool Part A: Ecol Genet Physiol (2014) 321(3):173-82. doi: 10.1002/jez.1847

110. Huber R, Smith K, Delago A, Isaksson K, Kravitz EA. Serotonin and aggressive motivation in crustaceans: altering the decision to retreat. Proc Natl Acad Sci USA (1997) 94(11):5939-42. doi: 10.1073/pnas.94.11.5939

111. Wongprasert K, Asuvapongpatana S, Poltana P, Tiensuwan M, Withyachumnarnkul B. Serotonin stimulates ovarian maturation and spawning in the black tiger shrimp Penaeus monodon. Aquaculture (2006) 261(4):1447-54. doi: 10.1016/j.aquaculture.2006.08.044

112. Tinikul Y, Poljaroen J, Tinikul R, Sobhon P. Changes in the levels, expression, and possible roles of serotonin and dopamine during embryonic development in the giant freshwater prawn, Macrobrachium rosenbergii. Gen Comp Endocrinol (2016) 225:71-80. doi: 10.1016/ j.ygcen.2015.09.018

113. Riquelmebugueno R. Incidence patterns of limb autotomy in the estuarine crab, Hemigrapsus crenulatus (H. Milne Edwards, 1837) (Brachyura, Grapsoidea) from a temperate estuary in the eastern South Pacific. Crustaceana (2006) 79(8):925-32. doi: 10.1163/156854006778815973

114. Yang XZ, Zhang C, Huang GY, Xu MJ, Cheng YX, Yang ZG, et al. Cellular and biochemical parameters following autotomy and ablation-mediated cheliped loss in the Chinese mitten crab, Eriocheir sinensis. Dev Comp Immunol (2018) 81:33-43. doi: 10.1016/j.dci.2017.11.003

115. Sainath SB, Swetha C, Reddy PS. What do we (need to) know about the melatonin in crustaceans? J Exp Zool Part A: Ecol Genet Physiol (2013) 319 (7):365-77. doi: 10.1002/jez.1800

116. Geihs MA, Vargas MA, Maciel FE, Caldas SS, Cruz BP, Primel EG, et al. Effect of melatonin in the antioxidant defense system in the locomotor muscles of the estuarine crab Neohelice granulata (Decapoda, Brachyura). Gen Comp Endocrinol (2010) 166(1):72-82. doi: 10.1016/j.ygcen.2009.09.018

117. Maciel FE, Ramos BP, Geihs MA, Vargas MA, Cruz BP, Meyer-Rochow VB, et al. Effects of melatonin in connection with the antioxidant defense system 
in the gills of the estuarine crab Neohelice granulata. Gen Comp Endocrinol (2010) 165(2):229-36. doi: 10.1016/j.ygcen.2009.07.009

118. Tome D, Bos C. Lysine requirement through the human life cycle. J Nutr (2007) 137(6):1642s-5s. doi: 10.1093/jn/137.6.1642S

119. Tanphaichitr V, Broquist HP. Role of Lysine and $\epsilon$-N-Trimethyllysine in Carnitine Biosynthesis. Nutr Rev (2009) 46(4):164-6. doi: 10.1111/j.17534887.1988.tb05413.x

120. Alam MS, Teshima S, Koshio S, Ishikawa M, Uyan O, Hernandez LHH, et al. Supplemental effects of coated methionine and/or lysine to soy protein isolate diet for juvenile kuruma shrimp, Marsupenaeus japonicus. Aquaculture (2005) 248(1-4):13-9. doi: 10.1016/j.aquaculture.2005.04.015

121. Ebeneezar S, Vijayagopal P, Srivastava PP, Gupta S, Kumar S, Varghese ST, et al. Dietary lysine requirement of juvenile Silver pompano, Trachinotus blochii (Lacepede, 1801). Aquaculture (2019) 511:734234. doi: 10.1016/ j.aquaculture.2019.734234

122. Feng ZF, Dong CH, Wang LL, Hu YJ, Zhu W. Optimal content and ratio of lysine to arginine in the diet of Pacific white shrimp, Litopenaeus vannamei. J Ocean Limnol (2013) 31(4):789-95. doi: 10.1007/s00343-013-2103-5

123. Madrid J, Pohlenz C, Viana MT, Lazo JP. Dietary lysine requirement for juvenile, Totoaba macdonaldi. Aquaculture (2019) 500:92-8. doi: 10.1016/ j.aquaculture.2018.10.003

124. Zhou F, Shao JJ, Xu R, Ma JJ, Xu ZR. Quantitative l-lysine requirement of juvenile black sea bream (Sparus macrocephalus). Aquac Nutr (2010) 16 (2):194-204. doi: 10.1111/j.1365-2095.2009.00651.x

125. Adesola AA, Jones CLW, Shipton TA. Dietary lysine requirement of juvenile dusky kob, Argyrosomus japonicus. Aquac Nutr (2018) 24(1):673-80. doi: $10.1111 /$ anu. 12576

126. Yang SD, Liu FG, Liou CH. Assessment of dietary lysine requirement for silver perch (Bidyanus bidyanus) juveniles. Aquaculture (2011) 312(14):102-8. doi: 10.1016/j.aquaculture.2010.12.011

127. Xie FJ, Ai QH, Mai KS, Xu W, Wang XJ. Dietary lysine requirement of large yellow croaker (Pseudosciaena crocea, Richardson 1846) larvae. Aquac Res (2012) 43(6):917-28. doi: 10.1111/j.1365-2109.2011.02906.x

128. Palma J, Andrade JP, Lemme A, Bureau DP. Quantitative dietary requirement of juvenile Atlantic ditch shrimp Palaemonetes varians for lysine, methionine and arginine. Aquac Res (2015) 46(8):1822-30. doi: 10.1111/are.12335

129. Dong XJ, Wu J, Shen Y, Chen JY, Miao SY, Zhang XJ, et al. Effects of different arginine/lysine level on growth performance, body composition and digestive enzyme activity of Macrobrachium rosenbergii. Aquac Nutr (2018) 24(3):1101-11. doi: 10.1111/anu.12649

130. Berge GE, Bakkemckellep AM, Lied E. In vitro uptake and interaction between arginine and lysine in the intestine of Atlantic salmon (Salmo salar). Aquaculture (1999) 179(1):181-93. doi: 10.1016/S0044-8486(99) 00161-1

131. Wu G, Meininger CJ. Regulation of nitric oxide synthesis by dietary factors. Annu Rev Nutr (2002) 22(1):61-86. doi: 10.1146/annurev.nutr.22. 110901.145329

132. Ma JJ, Xu Z, Shao Q, Xu JZ, Hung SSO, Hu WL, et al. Effect of dietary supplemental 1-carnitine on growth performance, body composition and antioxidant status in juvenile black sea bream, Sparus macrocephalus. Aquac Nutr (2008) 14(5):464-71. doi: 10.1111/j.1365-2095.2007.00551.x

133. Diasa S, Ozorio ROA, Goncalves J, Gartner F. Dietary L-Carnitine Supplementation Protected Turbot (Scophthalmusmaximus) Against Streptococcus parauberis Infection. J Appl Aquac (2011) 23(4):299-303. doi: $10.1080 / 10454438.2011 .626361$

134. Sabzi E, Mohammadiazarm H, Salati AP. Effect of dietary L-carnitine and lipid levels on growth performance, blood biochemical parameters and antioxidant status in juvenile common carp (Cyprinus carpio). Aquaculture (2017) 480:89-93. doi: 10.1016/j.aquaculture.2017.08.013

135. Gou GW, Jiang M, Wen H, Wu F, Liu W, Tian J. Effects of dietary L-carnitine supplementation on growth,hepatic lipid metabolism and antioxidant ability in GIFT,Oreochromis niloticus. Freshw Fish (2016) 46:81-8. doi: 10.13721/ j.cnki.dsyy.20160505.013

136. Li L, Limbu SM, Ma Q, Chen L, Zhang M, Du Z. The metabolic regulation of dietary L-carnitine in aquaculture nutrition: present status and future research strategies. Rev Aquacult (2019) 11(4):1228-57. doi: 10.1111/ raq. 12289
137. Brosnan JT, Brosnan ME. The sulfur-containing amino acids: an overview. J Nutr (2006) 136(6 Suppl):1636S-40S. doi: 10.1093/jn/136.6.1636S

138. Castro R, Rivera I, Blom HJ, Jakobs C, Tavares de Almeida I. Homocysteine metabolism, hyperhomocysteinaemia and vascular disease: an overview. J Inherit Metab Dis (2006) 29(1):3-20. doi: 10.1007/s10545-006-0106-5

139. Stadtman ER, Jackob M, Barbara SB, Rodney LL. Cyclic oxidation and reduction of protein methionine residues is an important antioxidant mechanism. Mol Cell Biochem (2002) 234-235(1):3-9. doi: 10.1007/978-14615-1087-1_1

140. Luo S, Levine RL. Methionine in proteins defends against oxidative stress. FASEB J (2009) 23(2):464-72. doi: 10.1096/fj.08-118414

141. Levine RL, Berlett BS, Moskovitz J, Mosoni L, Stadtman ER. Methionine residues may protect proteins from critical oxidative damage. Mech Ageing $\operatorname{Dev}$ (1999) 107(3):323-32. doi: 10.1016/S0047-6374(98)00152-3

142. Kim G, Weiss SJ, Levine RL. Methionine oxidation and reduction in proteins. Biochim Biophys Acta (2014) 1840(2):901-5. doi: 10.1016/j.bbagen.2013. 04.038

143. Mirzaaghatabar F, Saki AA, Zamani P, Aliarabi H, Matin HRH. Effect of different levels of diet methionine and metabolisable energy on broiler performance and immune system. Food Agric Immunol (2011) 22(2):93103. doi: $10.1080 / 09540105.2010 .530249$

144. Jankowski J, Kubinska M, Zdunczyk Z. Nutritional and Immunomodulatory Function of Methionine in Poultry Diets - a Review. Ann Anim Sci (2014) 14 (1):17-31. doi: 10.2478/aoas-2013-0081

145. Dai H, Coleman DN, Hu L, Martinez-Cortes I, Wang M, Parys C, et al. Methionine and arginine supplementation alter inflammatory and oxidative stress responses during lipopolysaccharide challenge in bovine mammary epithelial cells in vitro. J Dairy Sci (2020) 103(1):676-89. doi: 10.3168/ jds.2019-16631

146. Liu GC, Magnuson AD, Sun T, Tolba S, Starkey C, Whelan R, et al. Supplemental methionine exerted chemical form-dependent effects on antioxidant status, inflammation-related gene expression, and fatty acid profiles of broiler chicks raised at high ambient temperature1. J Anim Sci (2019) 97(12):4883-94. doi: 10.1093/jas/skz348

147. Baucharthevret C, Stoll BJ, Chacko SK, Burrin DG. Sulfur amino acid deficiency upregulates intestinal methionine cycle activity and suppresses epithelial growth in neonatal pigs. Am J Physiol Endocrinol Metab (2009) 296 (6):E1239-50. doi: 10.1152/ajpendo.91021.2008

148. Del Vesco AP, Gasparino E, Grieser Dde O, Zancanela V, Soares MA, Neto AR. Effects of methionine supplementation on the expression of oxidative stress-related genes in acute heat stress-exposed broilers. Br J Nutr (2015) 113(4):549-59. doi: 10.1017/S0007114514003535

149. Wu B, Li L, Ruan T, Peng X. Effect of methionine deficiency on duodenal and jejunal $\operatorname{IgA}(+) \mathrm{B}$ cell count and immunoglobulin level of broilers. Iran J Vet Res (2018) 19(3):165-71.

150. Khatlab AS, Del Vesco AP, Rodrigues Oliveira Neto A, Almeida FLA, Gasparino E. Dietary supplementation with free methionine or methionine dipeptide improves environment intestinal of broilers challenged with Eimeria spp. J Anim Sci (2019) 97(12):4746-60. doi: 10.1093/jas/skz339

151. Shen YB, Weaver AC, Kim SW. Effect of feed grade L-methionine on growth performance and gut health in nursery pigs compared with conventional DLmethionine. J Anim Sci (2014) 92(12):5530-9. doi: 10.2527/jas.2014-7830

152. Zhong H, Li H, Liu G, Wan H, Mercier Y, Zhang X, et al. Increased maternal consumption of methionine as its hydroxyl analog promoted neonatal intestinal growth without compromising maternal energy homeostasis. J Anim Sci Biotechnol (2016) 746(1):1-14. doi: 10.1186/s40104-016-0103-y

153. Sakkas P, Jones LA, Houdijk JG, Athanasiadou S, Knox DP, Kyriazakis I. Leucine and methionine deficiency impairs immunity to gastrointestinal parasites during lactation. Br J Nutr (2013) 109(2):273-82. doi: 10.1017/ S0007114512000931

154. Facanha FN, Oliveira-Neto AR, Figueiredo-Silva C, Nunes AJP. Effect of shrimp stocking density and graded levels of dietary methionine over the growth performance of Litopenaeus vannamei reared in a green-water system. Aquaculture (2016) 463:16-21. doi: 10.1016/j.aquaculture.2016.05.024

155. Fontagnedicharry S, Alamidurante H, Aragao C, Kaushik S, Geurden I. Parental and early-feeding effects of dietary methionine in rainbow trout (Oncorhynchus mykiss). Aquaculture (2017) 469:16-27. doi: 10.1016/ j.aquaculture.2016.11.039 
156. Luo Z, Liu YJ, Mai KS, Tian LX, Yang HJ, Tan XY, et al. Dietary Lmethionine requirement of juvenile grouper Epinephelus coioides at a constant dietary cystine level. Aquaculture (2005) 249(1-4):409-18. doi: 10.1016/j.aquaculture.2005.04.030

157. Mai KS, Wan JL, Ai QH, Xu W, Liufu ZG, Zhang L, et al. Dietary methionine requirement of large yellow croaker, Pseudosciaena crocea R. Aquaculture (2006) 253(1-4):564-72. doi: 10.1016/j.aquaculture.2005.08.010

158. Wang L, Ye L, Hua Y, Zhang GW, Li YH, Zhang JZ, et al. Effects of dietary dlmethionyl-dl-methionine (Met-Met) on growth performance, body composition and haematological parameters of white shrimp (Litopenaeus vannamei) fed with plant protein-based diets. Aquac Res (2019) 50(6):171830. doi: 10.1111/are.14064

159. Ronnestad I, Conceicao LEC, Aragao C, Dinis MT. Free Amino Acids Are Absorbed Faster and Assimilated More Efficiently than Protein in Postlarval Senegal Sole (Solea senegalensis). J Nutr (2000) 130(11):2809-12. doi: $10.1093 /$ jn/130.11.2809

160. Keembiyehetty CN, Gatlin DM. Total sulfur amino acid requirement of juvenile hybrid striped bass (Morone chrysops $\times$ M. saxatilis). Aquaculture (1993) 110(3-4):331-9. doi: 10.1016/0044-8486(93)90380-h

161. Seite S, Mourier A, Camougrand N, Salin B, Figueiredo-Silva AC, FontagneDicharry $\mathrm{S}$, et al. Dietary methionine deficiency affects oxidative status, mitochondrial integrity and mitophagy in the liver of rainbow trout (Oncorhynchus mykiss). Sci Rep (2018) 8(1):10151. doi: 10.1038/s41598018-28559-8

162. Cheng ZJ, Hardy RW, Blair M. Effects of supplementing methionine hydroxy analogue in soybean meal and distiller's dried grain-based diets on the performance and nutrient retention of rainbow trout [Oncorhynchus mykiss (Walbaum)]. Aquac Res (2003) 34(14):1303-10. doi: 10.1046/j.13652109.2003.00940.x

163. Elmada CZ, Huang WW, Jin M, Liang X, Mai K, Zhou Q. The effect of dietary methionine on growth, antioxidant capacity, innate immune response and disease resistance of juvenile yellow catfish (Pelteobagrus fulvidraco). Aquac Nutr (2016) 22(6):1163-73. doi: 10.1111/anu.12363

164. Lin HZ, Chen YF, Niu J, Zhou CP, Huang Z, Du Q, et al. Dietary Methionine Requirements of Pacific White Shrimp Litopenaeus vannamei, of Three Different Sizes. Isr J Aquacult-Bamid (2015) 67:1-10.

165. Nwanna LC, Pitatiratitivorakul S, Klinbunga S, Bonnuea S. Determination of methionine requirement of juvenile marine black giant tiger shrimp (Penaeus monodon). J Appl Sci Environ Manage (2019) 23(5):843-6. doi: 10.4314/jasem.v23i5.11

166. Dautreaux B, Toledano MB. ROS as signalling molecules: mechanisms that generate specificity in ROS homeostasis. Nat Rev Mol Cell Biol (2007) 8 (10):813-24. doi: 10.1038/nrm2256

167. Azad MAK, Huang P, Liu G, Ren W, Teklebrh T, Yan W, et al. Hyperhomocysteinemia and cardiovascular disease in animal model. Amino Acids (2018) 50(1):3-9. doi: 10.1007/s00726-017-2503-5

168. Lina EK, Stein EV, Helga R, Per MU. Plasma total cysteine, pregnancy complications, and adverse pregnancy outcomes: the Hordaland Homocysteine Study 1, 2. Am J Clin Nutr (2003) 77(2):467-72. doi: 10.1093/ ajcn/77.2.467

169. Kim CJ, Kovacs-Nolan J, Yang C, Archbold T, Fan MZ, Mine Y. L-cysteine supplementation attenuates local inflammation and restores gut homeostasis in a porcine model of colitis. Biochim Biophys Acta (2009) 1790(10):1161-9. doi: 10.1016/j.bbagen.2009.05.018

170. Song Z, Tong G, Xiao K, Jiao le F, Ke Y, Hu C. L-cysteine protects intestinal integrity, attenuates intestinal inflammation and oxidant stress, and modulates NF-kappaB and Nrf2 pathways in weaned piglets after LPS challenge. Innate Immun (2016) 22(3):152-61. doi: 10.1177/1753425 916632303

171. Srivastava MK, Sinha P, Clements VK, Rodriguez P, Ostrand-Rosenberg S. Myeloid-derived suppressor cells inhibit T-cell activation by depleting cystine and cysteine. Cancer Res (2010) 70(1):68-77. doi: 10.1158/00085472.CAN-09-2587

172. Grimble RF. The effects of sulfur amino acid intake on immune function in humans. J Nutr (2006) 136(6 Suppl):1660S-5S. doi: 10.1093/jn/136.6.1660S

173. Levring TB, Hansen AK, Nielsen BL, Kongsbak M, von Essen MR, Woetmann A, et al. Activated human CD4(+) T cells express transporters for both cysteine and cystine. Sci Rep (2012) 2(1):266-6. doi: 10.1038/ srep00266

174. Yan Z, Garg SK, Banerjee R. Regulatory T cells interfere with glutathione metabolism in dendritic cells and T cells. J Biol Chem (2010) 285(53):4152532. doi: 10.1074/jbc.M110.189944

175. Courtney-Martin G, Pencharz PB. Sulfur Amino Acids Metabolism From Protein Synthesis to Glutathione. In: D Dardevet, editor. The Molecular Nutrition of Amino Acids and Proteins. Boston: Academic Press (2016). doi: 10.1016/b978-0-12-802167-5.00019-0

176. Fang YZ, Yang S, Wu G. Free radicals, antioxidants, and nutrition. Nutrition (2002) 18(10):872-9. doi: 10.1016/s0899-9007(02)00916-4

177. Yee Aw T. Cellular redox: a modulator of intestinal epithelial cell proliferation. News Physiol Sci (2003) 18(5):201-4. doi: 10.1152/ nips.01448.2003

178. Townsend DM, Tew KD, Tapiero H. The importance of glutathione in human disease. Biomed Pharmacother (2003) 57(3-4):145-55. doi: 10.1016/ s0753-3322(03)00043-x

179. Wu G, Fang YZ, Yang S, Lupton JR, Turner ND. Glutathione metabolism and its implications for health. J Nutr (2004) 134(3):489-92. doi: 10.1093/jn/ 134.3.489

180. Ghezzi P. Role of glutathione in immunity and inflammation in the lung. Int J Gen Med (2011) 4:105-13. doi: 10.2147/IJGM.S15618

181. Morris D, Khurasany M, Nguyen T, Kim J, Guilford F, Mehta R, et al. Glutathione and infection. Biochim Biophys Acta (2013) 1830(5):3329-49. doi: 10.1016/j.bbagen.2012.10.012

182. Fang H, Meng F, Piao F, Jin B, Li M, Li W. Effect of Taurine on Intestinal Microbiota and Immune Cells in Peyer's Patches of Immunosuppressive Mice. Adv Exp Med Biol (2019) 1155:13-24. doi: 10.1007/978-981-13-8023-5_2

183. Marcinkiewicz J, Kontny E. Taurine and inflammatory diseases. Amino Acids (2014) 46(1):7-20. doi: 10.1007/s00726-012-1361-4

184. Benjakul S, Visessanguan W, Tanaka M. Inhibitory effect of cysteine and glutathione on phenoloxidase from kuruma prawn (Penaeus japonicus). Food Chem (2006) 98(1):158-63. doi: 10.1016/j.foodchem.2005.05.056

185. Yue Y, Liu Y, Tian L, Gan L, Yang H, Liang G, et al. The effect of dietary taurine supplementation on growth performance, feed utilization and taurine contents in tissues of juvenile white shrimp (Litopenaeus vannamei, Boone, 1931) fed with low-fishmeal diets. Aquac Res (2013) 44 (8):1317-25. doi: 10.1111/j.1365-2109.2012.03135.x

186. Wu G, Bazer FW, Dai Z, Li D, Wang J, Wu Z. Amino acid nutrition in animals: protein synthesis and beyond. Annu Rev Anim Biosci (2014) 2 (1):387-417. doi: 10.1146/annurev-animal-022513-114113

187. Wu G. Functional amino acids in growth, reproduction, and health. $A d v$ Nutr (2010) 1(1):31-7. doi: 10.3945/an.110.1008

188. Bonvini A, Coqueiro AY, Tirapegui J, Calder PC, Rogero MM. Immunomodulatory role of branched-chain amino acids. Nutr Rev (2018) 76(11):840-56. doi: 10.1093/nutrit/nuy037

189. Ananieva EA, Powell JD, Hutson SM. Leucine Metabolism in T Cell Activation: mTOR Signaling and Beyond. Adv Nutr (2016) 7(4):798S805S. doi: 10.3945/an.115.011221

190. Powell JD, Pollizzi KN, Heikamp EB, Horton MR. Regulation of immune responses by mTOR. Annu Rev Immunol (2012) 30(1):39-68. doi: 10.1146/ annurev-immunol-020711-075024

191. Lo YC, Lee CF, Powell JD. Insight into the role of mTOR and metabolism in T cells reveals new potential approaches to preventing graft rejection. Curr Opin Organ Transplant (2014) 19(4):363-71. doi: 10.1097/Mot.0000000000000098

192. Konno Y, Ashida T, Inaba Y, Ito T, Tanabe H, Maemoto A, et al. Isoleucine, an Essential Amino Acid, Induces the Expression of Human $\beta$ Defensin 2 through the Activation of the G-Protein Coupled Receptor-ERK Pathway in the Intestinal Epithelia. Food Sci Nutr (2012) 3(4):548-55. doi: 10.4236/ fns.2012.34077

193. Salzman NH, Ghosh D, Huttner KM, Paterson Y, Bevins CL. Protection against enteric salmonellosis in transgenic mice expressing a human intestinal defensin. Nature (2003) 422(6931):522-6. doi: 10.1038/ nature 01520

194. Deng YP, Jiang WD, Liu Y, Qu B, Jiang J, Kuang SY, et al. Dietary leucine improves flesh quality and alters mRNA expressions of Nrf2-mediated antioxidant enzymes in the muscle of grass carp (Ctenopharyngodon 
idella). Aquaculture (2016) 452:380-7. doi: 10.1016/j.aquaculture.2015. 11.007

195. Liu FJ, Liu YJ, Tian LX, Li XF, Zhang ZH, Yang HJ, et al. Quantitative dietary isoleucine requirement of juvenile Pacific white shrimp, Litopenaeus vannamei (Boone) reared in low-salinity water. Aquacult Int (2014) 22 (4):1481-97. doi: 10.1007/s10499-014-9761-y

196. Walsh NP, Blannin AK, Robson PJ, Gleeson M. Glutamine, exercise and immune function. Links and possible mechanisms. Sports Med (1998) 26 (3):177-91. doi: 10.2165/00007256-199826030-00004

197. Newsholme P. Why is L-glutamine metabolism important to cells of the immune system in health, postinjury, surgery or infection? J Nutr (2001) 131:2515S-22S. doi: 10.1093/jn/131.9.2515S

198. Murray PJ. Amino acid auxotrophy as a system of immunological control nodes. Nat Immunol (2016) 17(2):132-9. doi: 10.1038/ni.3323

199. Wang B, Wu G, Zhou Z, Dai Z, Sun Y, Ji Y, et al. Glutamine and intestinal barrier function. Amino Acids (2015) 47(10):2143-54. doi: 10.1007/s00726014-1773-4

200. Coutinho F, Castro C, Rufino-Palomares E, Ordonez-Grande B, Gallardo MA, Oliva-Teles A, et al. Dietary glutamine supplementation effects on amino acid metabolism, intestinal nutrient absorption capacity and antioxidant response of gilthead sea bream (Sparus aurata) juveniles. Comp Biochem Physiol A Mol Integr Physiol (2016) 191:9-17. doi: 10.1016/ j.cbpa.2015.09.012

201. Sikalidis AK. Amino acids and immune response: a role for cysteine, glutamine, phenylalanine, tryptophan and arginine in T-cell function and cancer? Pathol Oncol Res (2015) 21(1):9-17. doi: 10.1007/s12253-014-9860-0

202. Millamena OM, Teruel MB, Kanazawa A, Teshima S. Quantitative dietary requirements of postlarval tiger shrimp, Penaeus monodon, for histidine, isoleucine, leucine, phenylalanine and tryptophan. Aquaculture (1999) 179 (1):169-79. doi: 10.1016/S0044-8486(99)00160-X

203. Daubner SC, Le T, Wang S. Tyrosine hydroxylase and regulation of dopamine synthesis. Arch Biochem Biophys (2011) 508(1):1-12. doi: 10.1016/j.abb.2010.12.017

204. Chang ZW, Ke ZH, Chang CC. Roles of dopamine receptors in mediating acute modulation of immunological responses in Macrobrachium rosenbergii. Fish Shellfish Immunol (2016) 49:286-97. doi: 10.1016/ j.fsi.2015.12.046

205. Brunton JA, Baldwin MP, Hanna RA, Bertolo RF. Proline supplementation to parenteral nutrition results in greater rates of protein synthesis in the muscle, skin, and small intestine in neonatal Yucatan miniature piglets. J Nutr (2012) 142(6):1004-8. doi: 10.3945/jn.111.154534

206. Tomlinson C, Rafii M, Ball RO, Pencharz PB. Arginine can be synthesized from enteral proline in healthy adult humans. J Nutr (2011) 141(8):1432-6. doi: 10.3945/jn.110.137224

207. Wu G, Bazer FW, Burghardt RC, Johnson GA, Kim SW, Knabe DA, et al. Proline and hydroxyproline metabolism: implications for animal and human nutrition. Amino Acids (2011) 40(4):1053-63. doi: 10.1007/s00726-010-0715-Z

208. Tang H, Pang S. Proline Catabolism Modulates Innate Immunity in Caenorhabditis elegans. Cell Rep (2016) 17(11):2837-44. doi: 10.1016/ j.celrep.2016.11.038
209. Zhao L, Yang X, Cheng Y, Yang S. Effect of dietary histamine supplementation on growth, digestive enzyme activities and morphology of intestine and hepatopancreas in the Chinese mitten crab Eriocheir sinensis. Springerplus (2016) 5(1):552. doi: 10.1186/s40064-016-2105-9

210. Liu Y, Wang X, Hou Y, Yin Y, Qiu Y, Wu G, et al. Roles of amino acids in preventing and treating intestinal diseases: recent studies with pig models. Amino Acids (2017) 49(8):1277-91. doi: 10.1007/s00726-017-2450-1

211. Chen YP, Cheng YF, Li XH, Yang WL, Wen C, Zhuang S, et al. Effects of threonine supplementation on the growth performance, immunity, oxidative status, intestinal integrity, and barrier function of broilers at the early age. Poult Sci (2017) 96(2):405-13. doi: 10.3382/ps/pew240

212. Huai MY, Tian LX, Liu YJ, Xu AL, Liang GY, Yang HJ. Quantitative dietary threonine requirement of juvenile Pacific white shrimp, Litopenaeus vannamei (Boone) reared in low-salinity water. Aquac Res (2009) 40 (8):904-14. doi: 10.1111/j.1365-2109.2009.02181.x

213. Xie SW, Tian LX, Jin Y, Yang HJ, Liang GY, Liu YJ. Effect of glycine supplementation on growth performance, body composition and salinity stress of juvenile Pacific white shrimp, Litopenaeus vannamei fed low fishmeal diet. Aquaculture (2014) 418:159-64. doi: 10.1016/ j.aquaculture.2013.10.023

214. Ronharel N, Ghergurovich JM, Notarangelo G, Lafleur MW, Tsubosaka Y, Sharpe AH, et al. T Cell Activation Depends on Extracellular Alanine. Cell Rep (2019) 28(12):3011. doi: 10.1016/j.celrep.2019.08.034

215. Zhou H, Yu B, Gao J, Htoo JK, Chen D. Regulation of intestinal health by branched-chain amino acids. Anim Sci J (2018) 89(1):3-11. doi: 10.1111/ asj.12937

216. Yoneda J, Andou A, Takehana K. Regulatory Roles of Amino Acids in Immune Response. Curr Rheumatol Rev (2009) 5(4):252-8. doi: 10.2174/ 157339709790192567

217. Natividad JM, Agus A, Planchais J, Lamas B, Jarry AC, Martin R, et al. Impaired Aryl Hydrocarbon Receptor Ligand Production by the Gut Microbiota Is a Key Factor in Metabolic Syndrome. Cell Metab (2018) 28 (5):737-749 e4. doi: 10.1016/j.cmet.2018.07.001

218. Hauton C. The scope of the crustacean immune system for disease control. J Invertebr Pathol (2012) 110(2):251-60. doi: 10.1016/j.jip.2012.03.005

Conflict of Interest: YH was employed by the company Guangdong Yuequn Marine Biological Research and Development Co., Ltd.

The remaining authors declare that the research was conducted in the absence of any commercial or financial relationships that could be construed as a potential conflict of interest.

Copyright $\odot 2020$ Huang, Aweya, Zhu, Tran, Hong, Li, Yao and Zhang. This is an open-access article distributed under the terms of the Creative Commons Attribution License (CC BY). The use, distribution or reproduction in other forums is permitted, provided the original author(s) and the copyright owner(s) are credited and that the original publication in this journal is cited, in accordance with accepted academic practice. No use, distribution or reproduction is permitted which does not comply with these terms. 